\title{
Synthesis and evaluation of chromone derivatives as inhibitors of monoamine oxidase
}

\author{
Annah N. Mpitimpiti ${ }^{1}$ Jacobus P. Petzer ${ }^{1,2}$ (D) - Anél Petzer ${ }^{1,2}$ - Johannes H. L. Jordaan ${ }^{3}$. Anna C. U. Lourens ${ }^{1,2}$
}

Received: 14 November 2018 / Accepted: 6 January 2019 / Published online: 21 January 2019

(c) Springer Nature Switzerland AG 2019

\begin{abstract}
Based on reports that chromone compounds are good potency inhibitors of monoamine oxidase (MAO), the present study evaluates the effect of substitution with flexible side chains on the 3 position on MAO inhibition potency. Fifteen chromone derivatives were synthesised by reacting aromatic and aliphatic amines and alcohols with chromone 3-carboxylic acid in the presence of carbonyldiimidazole (CDI). This yielded chromane-2,4-dione and ester chromone derivatives. Generally, the esters exhibited weak MAO inhibition, while the chromane-2,4-dione derivatives showed promise as selective MAO-B inhibitors with $\mathrm{IC}_{50}$ values in the micromolar range. Compound 14b, 3-[(benzylamino)methylidene]-3,4-dihydro- $2 \mathrm{H}$-1-benzopyran-2,4-dione, was the most potent MAO-B inhibitor with an $\mathrm{IC}_{50}$ value of $638 \mu \mathrm{M}$. This compound was shown to be a reversible and competitive MAO-B inhibitor with a $K_{i}$ of $94 \mu \mathrm{M}$. In conclusion, the effect of chain elongation and introduction of flexible substituents on position 3 of chromone were explored and the results showed that aminomethylidene substitution is preferable over ester substitution. Good potency MAO-B inhibitors may act as leads for the design and development of therapy for Parkinson's disease where these agents reduce the central metabolism of dopamine.
\end{abstract}

\section{Graphical abstract}

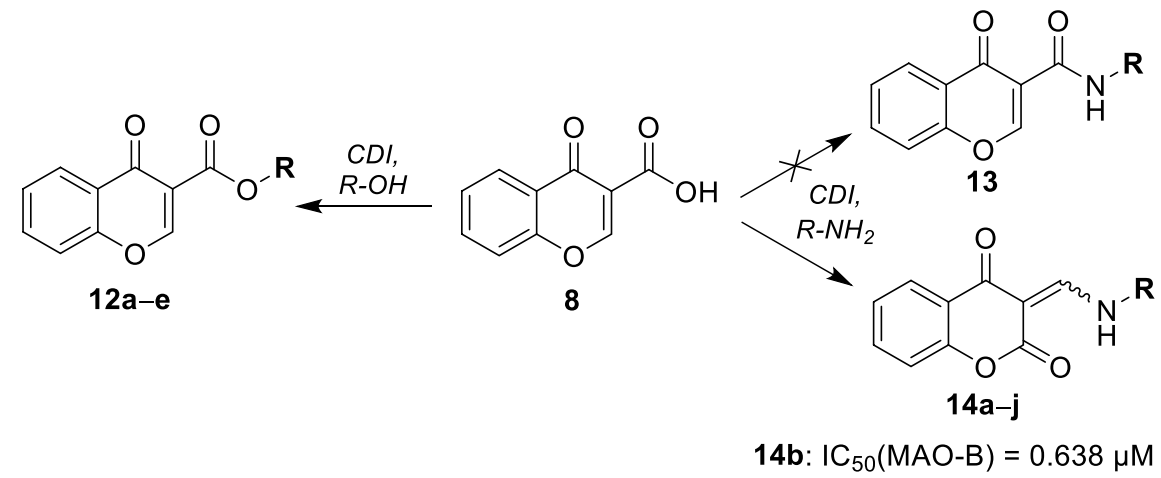

Chromane-2,4-dione derivatives show promise as selective MAO-B inhibitors.

Keywords Chromone $\cdot$ Chromandione $\cdot$ Monoamine oxidase $\cdot$ MAO $\cdot$ Inhibitor $\cdot$ Competitive $\cdot$ Parkinson's disease

\section{Introduction}

Electronic supplementary material The online version of this article (https://doi.org/10.1007/s11030-019-09917-8) contains supplementary material, which is available to authorized users.

Jacobus P. Petzer

jacques.petzer@nwu.ac.za

Extended author information available on the last page of the article
Parkinson's disease is the second most common neurodegenerative disorder affecting the brain and is the most common progressive neurodegenerative movement disorder [1-3]. Pathologically, Parkinson's disease is characterised by the death of the neurons in the substantia nigra and the presence 
of proteinaceous deposits known as Lewy bodies, resulting in the characteristic motor symptoms [4]. Due to its distinctive pathology, Parkinson's disease is primarily characterised by motor symptoms, although non-motor symptoms frequently appear especially in later stages of the disease [5]. Current treatment strategies are mainly aimed at restoring striatal dopamine activity with levodopa as the gold standard of therapy. Levodopa is administered in combination with carbidopa, an aromatic L-amino acid decarboxylase (AADC) inhibitor which prevents peripheral levodopa metabolism [1, 6]. Other dopaminergic therapies include dopamine agonists, which stimulate dopamine receptors, monoamine oxidase B (MAO-B) inhibitors and catechol-O-methyltransferase (COMT) inhibitors which reduce dopamine degradation [6]. Several potential neuroprotective or disease-modifying agents have been evaluated in clinical trials, but none have been conclusively proven to be neuroprotective in Parkinson's disease [7, 8]. As discussed below, however, a mechanistic rationale and preclinical evidence exist for a potential neuroprotective effect by MAO-B inhibitors.

MAO is an enzyme distributed extensively in higher eukaryotes and in mammals and is present in two isoforms, MAO-A and MAO-B [9]. The MAOs contain flavin adenine dinucleotide (FAD) as a cofactor and are bound to the outer mitochondrial membrane. The MAOs catalyse the oxidative deamination of various biogenic and dietary monoamines, and abnormal MAO levels may be associated with several disease states such as depression and Parkinson's disease [9]. Since MAO-A and MAO-B are products of distinctive genes, they differ with respect to their amino acid sequence, three-dimensional structure, tissue distribution as well as substrate and inhibitor specificity [10-12]. MAO-A preferentially deaminates serotonin, while MAO-B shows preference for benzylamine and phenethylamine as substrates. Both MAO isoforms deaminate dopamine equally well [9]. Since inhibition of the MAOs can potentially modulate neurotransmitter levels (for example dopamine) in the brain that are actively involved in the pathogenesis of some disease states [13, 14], MAO inhibitors have found application in the therapy of disorders such as Parkinson's disease $[15,16]$. In this respect, MAO-B inhibitors are effective as symptomatic treatment by compensating for diminished striatal dopamine levels; however, arresting disease progression remains the ultimate goal $[8,14]$.

As mentioned above, a mechanistic rationale exists for a potential neuroprotective effect by MAO-B inhibitors. The MAO catalytic cycle produces hydrogen peroxide as a byproduct which, via the Fenton reaction, is a precursor to harmful reactive oxygen species that may lead to oxidative damage and exacerbate neurodegeneration [14]. Thus, the inhibition of the MAO enzymes may reduce the formation of hydrogen peroxide and act as potential neuroprotectants [17]. Furthermore, MAO-B levels in several brain regions increase with age in humans, thus providing an additional rationale for the use of MAO-B inhibitors in Parkinson's disease with the aim of reducing oxidative neuronal damage [18]. Three MAO-B inhibitors are currently approved for use in Parkinson's disease. These are the mechanismbased inhibitors, rasagiline and selegiline, and the reversible inhibitor safinamide $[9,19]$. These inhibitors are specific for the MAO-B isoform since MAO-A inhibition may result a potentially fatal hypertensive crisis when taken with certain food [20,21]. For the design and development of new MAO-B inhibitors, isoform specificity is an important consideration.

Several heterocyclic scaffolds have been considered for the design of MAO inhibitors. These include coumarins, chalcones as well as chromones [22, 23]. Chromone (4H-1-benzopyran-4-one, 1) is an isomer of coumarin (2) and forms part of the flavone backbone (Fig. 1). Chromone derivatives occur in nature, and a large range of pharmacological activities such as immune stimulation [24, 25], antioxidant [26], anti-HIV [27], anticancer [28], biocidal [29], wound healing [30], antibacterial and antifungal activities [31] have been reported for these compounds. Due to their presence in plants, chromones are part of the human diet and generally exhibit low mammalian toxicity [28]. The chromone ring system is therefore considered to be a privileged scaffold due to its range of pharmacological and biological effects as well as the low risk of toxicity associated with chromone compounds [32].

The MAO inhibitory potential of chromone derivatives has been illustrated. For example, series of C6- and C7-substituted chromone derivatives were found to be potent, reversible MAO-B inhibitors. Compounds 3-6 are examples of high potency MAO-B inhibitors from these studies [22, 33, 34]. Although some of these chromones also exhibited $\mathrm{IC}_{50}$ values in the $\mathrm{nM}$ range for the inhibition of MAO-A, these compounds are specific inhibitors of the MAO-B isoform.

Interestingly, $\mathrm{C} 5$ substitution of chromone yields poor MAO-B inhibition when compared to the C6- and C7-substituted derivatives (e.g. 7) [35]. Also of interest is the finding that chromone 3-carboxylic acid (8) is a potent and specific MAO-B inhibitor $\left(\mathrm{IC}_{50}=0.048 \mu \mathrm{M}\right)$, while the presence of the carboxylic acid group in position 2 of the 4-pyrone nucleus (9) results in a loss of activity [36-38]. Similarly, phenylcarboxamide substitution on position 3 of the 4-pyrone nucleus results in potent MAO-B inhibition, with compounds $\mathbf{1 0}$ and $\mathbf{1 1}$ exhibiting $\mathrm{IC}_{50}$ values of 0.40 and $0.063 \mu \mathrm{M}$, respectively, while related 2-phenylcarboxamide substitution generally results in poor activity [37-39].

From the above discussion it is thus clear that chromones are suitable for the design of MAO-B-specific inhibitors. The MAO inhibitory activity of the chromones 
<smiles>O=c1ccoc2ccccc12</smiles>

1<smiles>O=c1ccc2ccccc2o1</smiles>

2<smiles>O=c1ccoc2ccc(OCc3ccc(Br)cc3)cc12</smiles>

${ }^{1 C_{50}}$ (MAO-A): $0.095 \mu \mathrm{M}$

$\mathrm{IC}_{50}$ (MAO-B): $0.0033 \mu \mathrm{M}$<smiles>O=c1ccoc2ccc(OCc3ccccc3)cc12</smiles>

4

$\mathrm{IC}_{50}$ (MAO-A): $3.30 \mu \mathrm{M}$

$\mathrm{IC}_{50}$ (MAO-B): $0.053 \mu \mathrm{M}$<smiles>O=c1ccoc2cc(OCc3ccc(Br)cc3)ccc12</smiles>

5<smiles>Cc1cc(=O)c2cc(OCc3ccccc3)ccc2o1</smiles>

6

$\mathrm{IC}_{50}$ (MAO-A): $0.592 \mu \mathrm{M}$ $\mathrm{IC}_{50}$ (MAO-B): $0.018 \mu \mathrm{M}$

$\mathrm{IC}_{50}$ (MAO-A): $21.8 \mu \mathrm{M}$ $\mathrm{IC}_{50}$ (MAO-B): $0.126 \mu \mathrm{M}$<smiles>O=c1ccoc2cccc(OCc3ccc(Br)cc3)c12</smiles>

7

$\mathrm{IC}_{50}$ (MAO-A): $52.9 \mu \mathrm{M}$ $\mathrm{IC}_{50}$ (MAO-B): $4.34 \mu \mathrm{M}$<smiles>O=C(O)c1coc2ccccc2c1=O</smiles>

8

$I_{50}$ (MAO-A): $>100 \mu \mathrm{M}$

$\mathrm{IC}_{50}$ (MAO-B): $0.048 \mu \mathrm{M}$<smiles>O=C(O)c1cc(=O)c2ccccc2o1</smiles>

$$
9
$$

$\mathrm{IC}_{50}$ (MAO-A): $>100 \mu \mathrm{M}$

$\mathrm{IC}_{50}$ (MAO-B): $>100 \mu \mathrm{M}$<smiles>O=C(Nc1ccccc1)c1coc2ccccc2c1=O</smiles>

10

$\mathrm{IC}_{50}$ (MAO-A): $>100 \mu \mathrm{M}$

$\mathrm{IC}_{50}$ (MAO-B): $0.40 \mu \mathrm{M}$<smiles>O=C(Nc1ccc(Cl)cc1)c1coc2ccccc2c1=O</smiles>

11

$\mathrm{IC}_{50}$ (MAO-A): $>100 \mu \mathrm{M}$

$\mathrm{IC}_{50}$ (MAO-B): $0.063 \mu \mathrm{M}$

Fig. 1 The structures of chromone (1), coumarin (2) and chromone derivatives 3-11 referred to in the text

has been validated, and this study will contribute by examining the MAO inhibition potential of $\mathrm{C} 3$-substituted chromones. Although the MAO inhibitory activity of rigid C3-substituted phenylcarboxamide derivatives has previously been investigated, the effect of chain elongation and the introduction of a more flexible substituent in this position have not been explored [37-39]. As discussed above, flexible substituents on positions 6 and 7, and rigid amide functions on position 3 have resulted in potent MAO inhibitors [33, 34, 37-39]. It is thus postulated that the introduction of a flexible ester- or amide-containing substituents on position 3 of chromone will result in potent, specific MAO inhibition. This study therefore attempted to synthesise chromone derivatives (12 and $\mathbf{1 3}$ ) where flexible substituents will be attached via ester and amide functions on position 3 of chromone (Fig. 2). The chromone derivatives were synthesised by reacting aromatic and aliphatic alcohols and amines with chromone 3-carboxylic acid (8). As will be shown, this yielded the anticipated ester chromone derivatives (12), while the amide derivatives 13 were not obtained. Instead, the reactions of amines with chromone 3-carboxylic acid yielded chromane-2,4-diones (14).<smiles>O=C(O)c1coc2ccccc2c1=O</smiles>

8<smiles>CC(C)(C)CC(=O)c1coc2ccccc2c1=O</smiles><smiles>[R]NC=C1C(=O)Oc2ccccc2C1=O</smiles>

Fig. 2 The general structures of chromone derivatives 12-14 that were considered for this study, and the synthesis of ester chromone derivatives (12a-e) and 3-aminomethylidene-2,4-chromandiones (14a-j). Reagents and conditions a CDI, DMF, $60{ }^{\circ} \mathrm{C}, 2 \mathrm{~h}$; b R-OH, DMF, rt, overnight; $\mathbf{c} \mathrm{R}-\mathrm{NH}_{2}$, DMF, rt, overnight 


\section{Results}

\section{Chemistry}

The aim of this study was to synthesise ester (12) and amide (13) derivatives of chromone. The synthesis of these compounds was attempted using standard literature procedures with the synthetic strategy employed for both series involving a coupling reaction of chromone 3-carboxylic acid (8) with an equimolar quantity of an alcohol or amide in the presence of carbonyldiimidazole (CDI) as coupling reagent (Fig. 2) [40]. In total, 15 compounds were synthesised in poor to moderate yields (13-70\%). All synthesised compounds were characterised by NMR and infrared spectroscopy and mass spectrometry. For all compounds, the mass data correlated well with the calculated mass values. Purity of the compounds was determined by HPLC and was between 79 and 100\%. Decomposition of the ester derivatives was observed over time. Melting points generally correlated with reported literature values; however, differences in the melting points of the chromane-2,4-diones (14) when compared to the literature values are most likely due to differences in the ratios of the $E / Z$-isomers [41].

NMR assignments were based on interpretation of both 1D NMR $\left({ }^{13} \mathrm{C},{ }^{1} \mathrm{H}\right.$, DEPT) and 2D NMR (COSY, HSQC, HMBC) spectra, while NMR data of known compounds were also considered. The results of the attempted synthesis of amide derivatives $\mathbf{1 3}$ were initially surprising, as analogous amide derivatives were obtained using related methodology [38, 42]. However, in a study done by Cagide and co-workers [39], similar results to this study were obtained using PyBOP as coupling reagent in the presence of $N, N$-diisopropylethylamine (DIPEA), while Gaspar and co-workers used PyBOP or BOP as coupling agent, also in the presence of DIPEA [38]. Under acidic conditions $\left(\mathrm{POCl}_{3}\right.$ in DMF), however, the target carboxamide derivatives could be obtained [39]. The formation of the chromane-2,4-diones versus the carboxamide derivatives is thus dependant on the experimental conditions, and activation of the carboxylic acid probably precedes nucleophilic attack by the amine on C2. Careful consideration of the NMR data revealed that the desired amide derivatives were in fact not synthesised, but that the products that were obtained were the structurally related chromane-2,4-diones 14 . In the ${ }^{1} \mathrm{H}$ NMR spectra for example, the presence of a methine proton (H-9) that occurs as a doublet coupling to the adjacent imino proton provided evidence that the keto-enamines were obtained and not the desired amides (where both $\mathrm{H}-2$ and the NH signals are expected to appear as singlets). A crystal structure was obtained for compound $\mathbf{1 4 j}$ (Fig. 3) and provided further confirmation that this was indeed the case.

A reaction mechanism for the formation of the chromane2,4-dione derivatives, based on literature reports for related systems, is illustrated in Fig. 4 [39, 43]. It is postulated that the carboxylic acid is activated by CDI as expected. Reaction of the amine however does not result in the displacement of imidazole, but leads to ring opening of the pyrone ring, followed by ring closure through lactonisation with loss of imidazole.

NMR data further revealed that the chromane-2,4-diones exist as mixtures of isomers. In the proton spectra there are two distinct NH signals as well as two signals for H-9 and generally also for $\mathrm{H}-5$. Double signals of almost all carbons also occur, but are especially clear for C-4, C-2 and C-9. A literature survey revealed that these compounds exist as mixtures of $E$ - and $Z$-isomers, with one isomer predominating (Fig. 5) [41, 44-47]. In the ${ }^{1} \mathrm{H}$ NMR spectrum of compound 14i for example, the two NH signals are present at 13.57 and $11.91 \mathrm{ppm}$ for the major and minor products, respectively. It is postulated that the more downfield signal corresponds to the $E$-isomer, where the NH forms a short, strong intramolecular hydrogen bond with the $\mathrm{C}(4)=\mathrm{O}$ group. The $\mathrm{NH}$ signal for the $Z$-isomer (thus at $11.91 \mathrm{ppm}$ ) also forms a hydrogen bond with the ester carbonyl (C2), but it has been reported that this bond is significantly weaker $[41,44]$. On the other hand, the H-9 proton of the minor
Fig. 3 ORTEP drawing representing the crystal structure of the $E$-isomer of compound $\mathbf{1 4} \mathbf{j}$

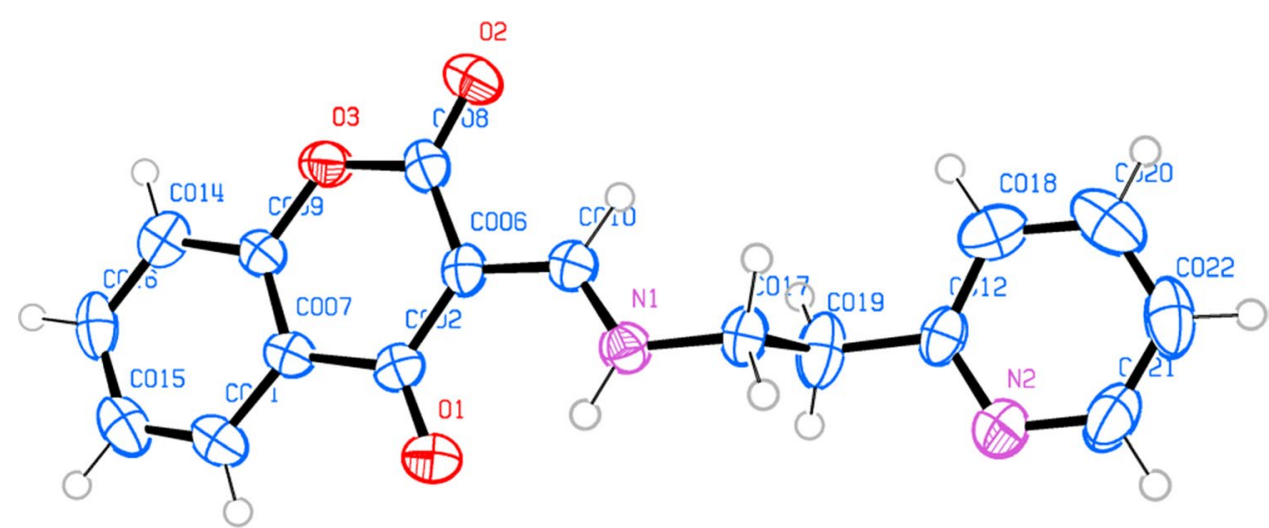


<smiles>[R]NC=C(C(=O)c1ccccc1O)C(=O)c1ccccc1O</smiles>

Fig. 4 Proposed mechanism for aminomethylidene-2,4-chromandione formation (adapted from the literature) [39, 43]<smiles>O=C1Oc2ccccc2C(=O)/C1=C/NP</smiles>

(Z)-isomer<smiles>[R]N/C=C1/C(=O)Oc2ccccc2C1=O</smiles>

(E)-isomer
Fig. 5 The $E$ - and $Z$-isomers of the chromane-2,4-diones obtained in this study

isomer (presumably the $Z$-isomer) is found more downfield $(9.71 \mathrm{ppm})$ than that of the major $E$-isomer ( $9.61 \mathrm{ppm})$.

In the ${ }^{13} \mathrm{C}$ NMR spectrum of $\mathbf{1 4} \mathbf{i}$, the signal for the C-4 carbonyl at $182.4 \mathrm{ppm}$ for the major ( $E$-isomer) is shifted downfield compared to the signal of the minor $Z$-isomer at $178.8 \mathrm{ppm}$. The opposite is observed for the C-2 carbonyl, where the signal for the minor $Z$-isomer is more downfield (165.3 ppm) compared to the signal for the major $E$-isomer which is present at $163.3 \mathrm{ppm}$. This is due to the possibility that $\mathrm{C}-4$ carbonyl oxygen is hydrogen bonded to the $\mathrm{NH}$ proton in the $E$-isomer, whereas $\mathrm{C}-2$ carbonyl oxygen is hydrogen bonded to the $\mathrm{NH}$ for the minor $Z$-isomer. The carbonyl that undergoes hydrogen bonding therefore occurs further downfield than its non-hydrogen-bonded counterpart $[41,44]$. Since similar observations were made for all the 3-chromane-2,4-diones synthesised in this study, it is proposed that the $E$-isomer is the major isomer. According to the literature further evidence for the $E$-isomer as major product is provided by molecular calculations where the energy of formation of the $E$-keto-enamine is lower than that of the Z-keto-enamine form [41].

NMR assignments were based on chemical shifts, integration, multiplicities, coupling constants, correlations in
HMBC, HSQC and COSY spectra as well as DEPT data. The assignments and observed HMBC correlations of the major isomer of compound 14i are shown in Table $\mathrm{S} 1$ (supplementary) as an example. The most characteristic difference between the ${ }^{1} \mathrm{H}$ NMR spectra of these chromane2,4-diones (14) and those of the ester derivatives (12) is the presence of $\mathrm{H}-9$ which appears as a doublet coupling to the adjacent imino proton. The NH signals further also occur quite far downfield due to intramolecular hydrogen bonding with $\mathrm{C}(4)=\mathrm{O}$ (major isomer) or $\mathrm{C}(2)=\mathrm{O}$ (minor isomer). The shifts of the aromatic protons of ring $\mathrm{A}$ of these derivatives were similar to those of the ester derivatives and were assigned as follows for compound 14i: $\delta_{\mathrm{H}}$ : 8.05 (H-5), 7.63-7.56 (H-7), 7.32-7.23 (H-6 and H-8). The ${ }^{13} \mathrm{C}$ NMR spectrum for compound $\mathbf{1 4}$ i showed the presence of 30 signals, thus providing further evidence of the presence of two isomers. Analysis of the ${ }^{13} \mathrm{C}$ spectrum together with the DEPT 135 spectra indicated the presence of six quaternary carbons and nine $\mathrm{CH}$ carbons (for each isomer). Chemical shifts and observed 2D correlations were used to further assign carbon signals (Table S1, supplementary). Similar correlations were observed in all cases for the minor $Z$-isomer.

Ratios of the $E: Z$ mixtures may be calculated using the integral intensities of the H-9 signals. Interestingly, Traven and co-workers noted that the rate of equilibration between these isomers strongly depends on solvent polarity, where for 3-(p-tolyliminomethyl)chromane-2,4-dione equilibrium is almost immediately established after dissolution in methanol, $4 \mathrm{~h}$ after dissolution in DMSO and $24 \mathrm{~h}$ after dissolution in chloroform [41]. Thus, if a different solvent was used to dissolve these compounds and if they were observed over time, the observed ratios of these isomers could change. In order to investigate the effect of temperature on the ratios 
of isomers, variable temperature NMR experiments were performed. The results with compound $\mathbf{1 4 b}$ are shown in Fig. S1 (supplementary). Based on these results it appears that changes in temperature from -10 to $45^{\circ} \mathrm{C}$ do not alter the observed ratios of the $E$ - and $Z$-isomers.

\section{Monoamine oxidase inhibition: $I_{50}$ values}

The compounds synthesised in this study were evaluated as inhibitors of MAO-A and MAO-B. Recombinant human MAO-A and MAO-B enzymes were used for this purpose. MAO activity was measured by making use of a fluorometric assay with kynuramine as the enzyme-substrate. Kynuramine is a non-selective substrate for both MAO-A and MAO-B and is oxidised to yield 4-hydroxyquinoline, a metabolite that fluoresces in alkaline media $[48,49]$. By measuring MAO activity in the absence and presence of different concentrations of the test inhibitors, sigmoidal plots of enzyme activity versus the logarithm of inhibitor concentration were constructed from which the $\mathrm{IC}_{50}$ values were estimated. Figure 6 gives examples of representative sigmoidal plots.

The results of the MAO inhibition studies are given in Tables 1 and 2. Selectivity index (SI) values provide an indication of the selectivity for the inhibition of MAO-B over the MAO-A isoform. From Table 1 it is apparent that the ester derivatives are generally weak MAO-A and MAO-B inhibitors with $\mathrm{IC}_{50}$ values $>9 \mu \mathrm{M}$. Comparing the MAO-A and MAO-B potencies of compound 12a (phenyl substituted) and 12b (benzyl substituted), it is evident that the benzyl derivative is more potent than the phenyl derivative. Thus, chain elongation from phenyl to benzyl improved MAO inhibition activity. A similar trend is observed when the activity of compound 12c is compared to that of $\mathbf{1 2 a}$.

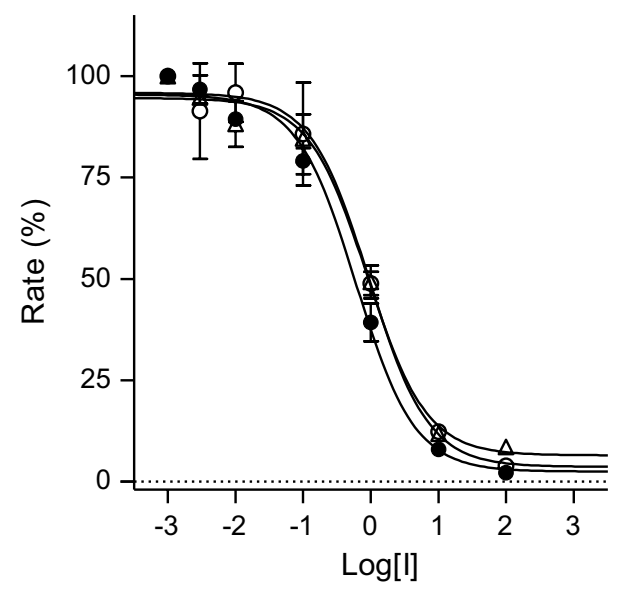

Fig. 6 Sigmoidal plots for the inhibition of MAO-B by 14a (open circles), 14b (filled circles) and 14c (triangles). Each data point represents a mean \pm SD of triplicate determinations
Table $1 \mathrm{IC}_{50}$ values for the inhibition of MAO-A and MAO-B by ester chromone derivatives (12)<smiles>[R]OC(=O)c1coc2ccccc2c1=O</smiles>

\begin{tabular}{|c|c|c|c|c|}
\hline & \multirow[t]{2}{*}{$\mathrm{R}$} & \multicolumn{2}{|l|}{$\mathrm{IC}_{50}(\mu \mathrm{M})^{\mathrm{a}}$} & \multirow[t]{2}{*}{$\mathrm{SI}^{\mathrm{b}}$} \\
\hline & & MAO-A & MAO-B & \\
\hline $12 \mathrm{a}$ & & $66.7 \pm 2.06$ & $27.3 \pm 0.946$ & 2.4 \\
\hline $12 b$ & & $26.8 \pm 0.560$ & $14.7 \pm 0.416$ & 1.8 \\
\hline $12 \mathrm{c}$ & & $21.6 \pm 8.72$ & $14.8 \pm 1.09$ & 1.5 \\
\hline 12d & & $18.5 \pm 8.85$ & $12.0 \pm 0.400$ & 1.5 \\
\hline $12 \mathrm{e}$ & & $18.6 \pm 3.27$ & $9.74 \pm 0.123$ & 1.9 \\
\hline
\end{tabular}

${ }^{\mathrm{a}}$ All values are expressed as the mean $\pm \mathrm{SD}$ of triplicate determinations

${ }^{\mathrm{b}}$ Selectivity index $(\mathrm{SI})=\mathrm{IC}_{50}(\mathrm{MAO}-\mathrm{A}) / \mathrm{IC}_{50}(\mathrm{MAO}-\mathrm{B})$

4-Chlorophenyl substitution (12c) has improved MAO inhibition activity compared to unsubstituted phenyl side chain (12a). This trend is also observed when comparing compound 12e, a 4-chlorobenzyl-substituted derivative, to compound 12b. Comparing the 4-chlorophenyl (12c) with 3-chlorophenyl substitution (12d), it is clear that the position of the chlorine does not significantly affect MAO inhibition activity. It may therefore be concluded that elongation of the side chain from phenyl to benzyl and substituting with a chlorine on the 3'- or 4'-position enhance MAO inhibition activity of the ester derivatives.

From Table 2 it may be concluded that the chromane2,4-diones are selective inhibitors of MAO-B with $\mathrm{IC}_{50}$ values in the micromolar range. Generally, the chromane2,4-diones are more potent MAO-B inhibitors than the ester derivatives. (They are however weaker inhibitors of MAOA.) Compound $14 \mathrm{~b}$ is the most potent MAO-B inhibitor with an $\mathrm{IC}_{50}$ value of $0.638 \mu \mathrm{M}$, while $\mathbf{1 4 d}$ is the most selective MAO-B inhibitor with a SI value of 218. MAO-B inhibition increases with side chain elongation from compound $14 \mathbf{a}$ to 14b (phenyl to benzyl) and is similar for compounds 14a and $\mathbf{1 4 c}$, but from compounds $14 \mathrm{~d}$ to $\mathbf{1 4 e}$, as further chain elongation occurs, MAO-B inhibitory activity decreases. Comparing the MAO-A and MAO-B inhibition potencies of compounds $14 \mathrm{f}, 14 \mathrm{~g}$ and $14 \mathrm{~h}$, it is evident that chain 
Table $2 \mathrm{IC}_{50}$ values for the inhibition of MAO-A and MAO-B by 3-aminomethylidene-2,4-chromandiones (14)<smiles>[R]NC=C1C(=O)Oc2ccccc2C1=O</smiles>

\begin{tabular}{|c|c|c|c|c|}
\hline & \multirow[t]{2}{*}{$\mathrm{R}$} & \multicolumn{2}{|l|}{$\mathrm{IC}_{50}(\mu \mathrm{M})^{\mathrm{a}}$} & \multirow[t]{2}{*}{$\mathrm{SI}^{\mathrm{b}}$} \\
\hline & & MAO-A & MAO-B & \\
\hline $14 a$ & & $79.6 \pm 30.2$ & $0.947 \pm 0.125$ & 84 \\
\hline $14 b$ & & $77.9 \pm 25.5$ & $0.638 \pm 0.287$ & 122 \\
\hline $14 c$ & & $101 \pm 3.49$ & $0.897 \pm 0.166$ & 113 \\
\hline 14d & & $312 \pm 89.1$ & $1.43 \pm 0.103$ & 218 \\
\hline $14 e$ & & $155 \pm 19.1$ & $142 \pm 47.2$ & 1.1 \\
\hline $14 f$ & & $72.1 \pm 6.53$ & $3.08 \pm 0.279$ & 23 \\
\hline $14 g$ & & $288 \pm 61.8$ & $\mathrm{NI}^{\mathrm{c}}$ & - \\
\hline $14 \mathrm{~h}$ & & $\mathrm{NI}^{\mathrm{c}}$ & $\mathrm{NI}^{\mathrm{c}}$ & - \\
\hline $14 \mathbf{i}$ & & $73.1 \pm 20.4$ & $38.7 \pm 1.73$ & 1.9 \\
\hline $14 j$ & & $41.6 \pm 2.29$ & $16.6 \pm 1.04$ & 2.5 \\
\hline
\end{tabular}

${ }^{\mathrm{a}}$ All values are expressed as the mean $\pm \mathrm{SD}$ of triplicate determinations

${ }^{\mathrm{b}}$ Selectivity index $(\mathrm{SI})=\mathrm{IC}_{50}(\mathrm{MAO}-\mathrm{A}) / \mathrm{IC}_{50}(\mathrm{MAO}-\mathrm{B})$

${ }^{\mathrm{c}}$ No inhibition at a maximum tested concentration of $100 \mu \mathrm{M}$

elongation results in loss of activity. Interestingly, compounds $14 \mathrm{~g}$ and $14 \mathrm{~h}$ do not inhibit MAO-B. This may be due to lengthening of the side chain in combination with the addition of a sterically large chlorine. Comparing the MAO inhibition activities of compounds $14 \mathbf{a}-\mathbf{c}$ with those of compounds $\mathbf{1 4 f}-\mathbf{h}$, it may be concluded that chlorine substitution reduces MAO-B inhibition potency. The compounds with pyridine-containing side chains (compounds $\mathbf{1 4} \mathbf{i}$ and 14j) both show poor MAO inhibition; however, with chain elongation from pyridyl (14i) to ethylpyridyl (14j) a twofold increase in MAO inhibition is observed. The results further show that the chromane-2,4-diones $\mathbf{1 4}$ are more potent
MAO-B inhibitors that the ester chromone derivatives 12 . For example, the phenyl-substituted compound, 14a, is approximately 28 -fold more potent than 12a. Similarly, the chromane-2,4-diones $\mathbf{1 4 b}$ and $\mathbf{1 4 f}$ are also significantly more potent MAO-B inhibitors than their corresponding ester derivatives $\mathbf{1 2 b}$ and $\mathbf{1 2 c}$. It should be noted that the 3-aminomethylidene-2,4-chromandiones are represented by inseparable mixtures of $E$ - and $Z$-isomers, and the MAO inhibition potencies recorded are that of the mixtures. The observation that chromane-2,4-diones are weak inhibitors of MAO-A is in agreement with a recent report of the MAO inhibition properties of four 3-[(phenylamino)methylidene] chromane-2,4-dione derivatives [39]. These compounds did not inhibit human MAO-A at a maximal tested concentration of $10 \mu \mathrm{M}$. The $\mathrm{IC}_{50}$ values reported for the inhibition of human MAO-B by $\mathbf{1 4 a}(0.268 \mu \mathrm{M})$ and $\mathbf{1 4 f}(0.065 \mu \mathrm{M})$, however, differ significantly from the values recorded in the present study. The reason for this discrepancy is unclear, but may be related to different experimental approaches to measuring MAO activity.

\section{Monoamine oxidase inhibition: reversibility}

The reversibility of the MAO-B inhibition by compound 14b was examined using dialysis [49]. Compound 14b was selected since it is the most potent MAO-B inhibitor of this study. None of the study compounds were potent MAO-A inhibitors, and therefore reversibility of MAO-A inhibition was not examined. For these studies MAO-B and compound $\mathbf{1 4 b}$ (at $4 \times \mathrm{IC}_{50}$ ) were combined and preincubated for $15 \mathrm{~min}$. As controls, the MAO-B enzyme was similarly preincubated in the absence of inhibitor (negative control) and presence of the irreversible MAO-B inhibitor, $(R)$-deprenyl (positive control). The preincubated mixtures were subsequently dialysed for $24 \mathrm{~h}$ and diluted twofold to yield a final inhibitor concentration of $2 \times \mathrm{IC}_{50}$. The residual MAO-B activity of the diluted samples was measured and is shown in Fig. 7. Non-dialysed mixtures of MAO-B and the test inhibitor were maintained over the same time period ( $24 \mathrm{~h}$ ) for comparison. The results show that the inhibition of MAO-B by compound $\mathbf{1 4 b}$ is completely reversed after $24 \mathrm{~h}$ of dialysis. After dialysis of mixtures containing $\mathbf{1 4 b}$ and MAO-B, the MAO-B catalytic activity was recovered to $115 \%$ of the negative control value $(100 \%)$. This suggests that compound $\mathbf{1 4 b}$ is a reversible inhibitor of MAOB. After dialysis of the positive control samples containing $(R)$-deprenyl and MAO-B, catalytic activity is not recovered with only $3 \%$ activity remaining. As anticipated, inhibition of MAO-B by $\mathbf{1 4 b}$ persists in non-dialysed samples with the residual activity at $41 \%$.

A set of Lineweaver-Burk plots were also constructed to determine the mode of MAO-B inhibition of $\mathbf{1 4 b}$. Four Lineweaver-Burk plots were constructed with the first plot 


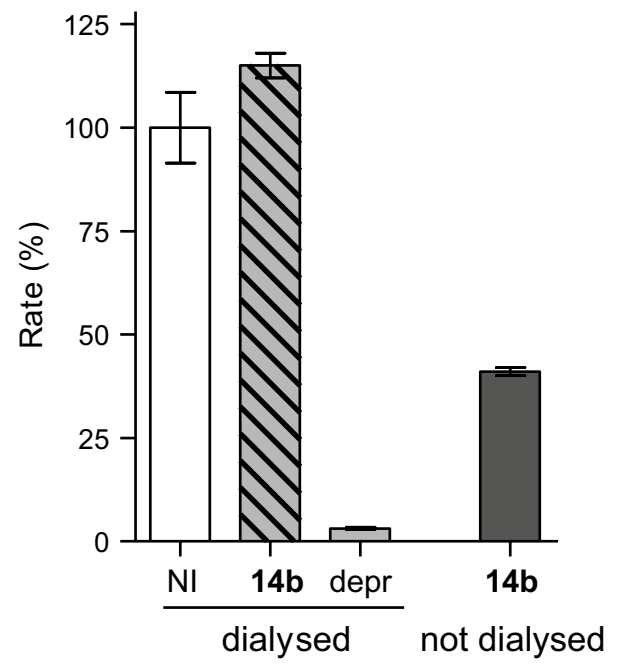

Fig. 7 The reversibility of inhibition of MAO-B by compound $\mathbf{1 4 b}$. MAO-B was preincubated and dialysed in the absence of inhibitor (NI-dialysed) and the presence of inhibitor $14 \mathbf{b}(\mathbf{1 4 b}$-dialysed) and $(R)$-deprenyl (depr-dialysed). The residual MAO-B activities were recorded and are given as the mean \pm standard deviation. The residual activities of non-dialysed mixtures of MAO-B and 14b were also recorded (14b-not dialysed)

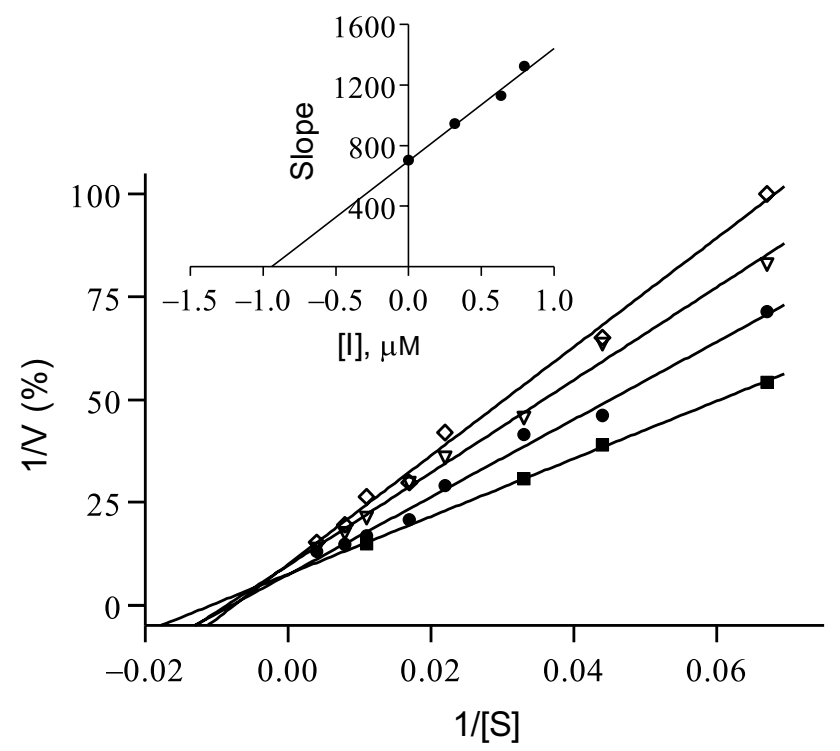

Fig. 8 Lineweaver-Burk plots of the inhibition of MAO-B by $\mathbf{1 4 b}$. The inset is a plot of the slopes of the Lineweaver-Burk plots versus inhibitor concentration. Key: no inhibitor (filled squares); inhibitor concentration $=1 / 2 \times \mathrm{IC}_{50}($ circles $), 1 \times \mathrm{IC}_{50}($ triangles $), 1 \frac{1}{4} \times \mathrm{IC}_{50}($ diamonds)

prepared in the absence of inhibitor, while the remaining three plots were prepared in the presence of different concentrations of $\mathbf{1 4 b}\left(1 \frac{1}{2} \times \mathrm{IC}_{50}, 1 \times \mathrm{IC}_{50} ; 1 \frac{1 / 4}{4} \times \mathrm{IC}_{50}\right)$. Kynuramine at eight different concentrations $(15-250 \mu \mathrm{M})$ was used as substrate. The results are given in Fig. 8 and show that the lines are linear and intersect at a single point just to the left of the $y$-axis. This suggests that 14b interacts competitively with the MAO-B enzyme. From a replot of the slopes of the Lineweaver-Burk plots versus inhibitor concentration, the $K_{i}$ value is estimated at $0.94 \mu \mathrm{M}$.

\section{Discussion and conclusion}

This study attempted to synthesise ester (12a-e) and amide (13) derivatives of chromone by reacting chromone 3-carboxylic acid with aromatic and aliphatic alcohols and amines in the presence of CDI. While the target esters were successfully synthesised, the reaction of chromone 3-carboxylic acid with amine compounds yielded the chromane-2,4-diones, which was not entirely unexpected $(\mathbf{1 4 a}-\mathbf{j})$. Qualitative analysis using 1D and 2D NMR and X-ray crystallography assisted in structure elucidation of the chromane-2,4-diones. The results of the MAO inhibition studies showed that the ester derivatives are weak MAO inhibitors, while several of the chromane-2,4-diones exhibited good MAO-B inhibition potencies. The most potent MAO-B inhibitor is compound $14 \mathrm{~b}$ with an $\mathrm{IC}_{50}$ value of $0.638 \mu \mathrm{M}$. This compound is much less potent as an MAO-A inhibitor with an $\mathrm{IC}_{50}$ of $77.9 \mu \mathrm{M}$. It was further established that $\mathbf{1 4 b}$ is a reversible MAO-B inhibitor. Compared to the reversible MAO-B selective inhibitor, lazabemide $\left(\mathrm{IC}_{50}=0.091 \mu \mathrm{M}\right)$, which was evaluated under identical experimental conditions, compound $\mathbf{1 4 b}$ is however a lower potency MAO inhibitor [50]. Similarly, the MAO-B inhibition potency of $\mathbf{1 4 b}$ is significantly lower compared to previously reported C6- and C7-substituted chromones [22, 33, 34]. This is exemplified by chromones 3-5, which are at least an order of magnitude more potent MAO-B inhibitors compared to $\mathbf{1 4 b}$.

Molecular docking is considered to be a useful tool for predicting potential binding orientations and interactions of ligands in the MAO active site [51-53]. Based on the crystal structures of MAO-B in complex with reversible inhibitors, it may be expected that chromane-2,4-diones will bind to the active site with the chromane-2,4-dione moiety in proximity to the FAD, the most polar region. Here the chromane2,4-dione moiety can establish hydrogen bonding with amino acid residues and water molecules. The 3 -aminomethylidene side chain is expected to extend into the entrance cavity, which is reported to be lined by mostly non-polar residues. To illustrate this, the trans and cis isomers of $\mathbf{1 4 b}$ were docked into the active site of MAO-B (PDB: 2Z5X) [54] with the CDOCKER module of Discovery Studio 3.1 (Accelrys) according to the reported protocol [49]. The results are given in Fig. 9 and show that both isomers indeed bind with the chromane-2,4-dione moiety placed in the substrate cavity. Interestingly, the binding orientations of the trans and cis isomers are very similar. While conventional 
Fig. 9 Overlay of the predicted binding orientations of the trans (purple) and cis (yellow) isomers of $\mathbf{1 4 b}$ in the MAO-B active site

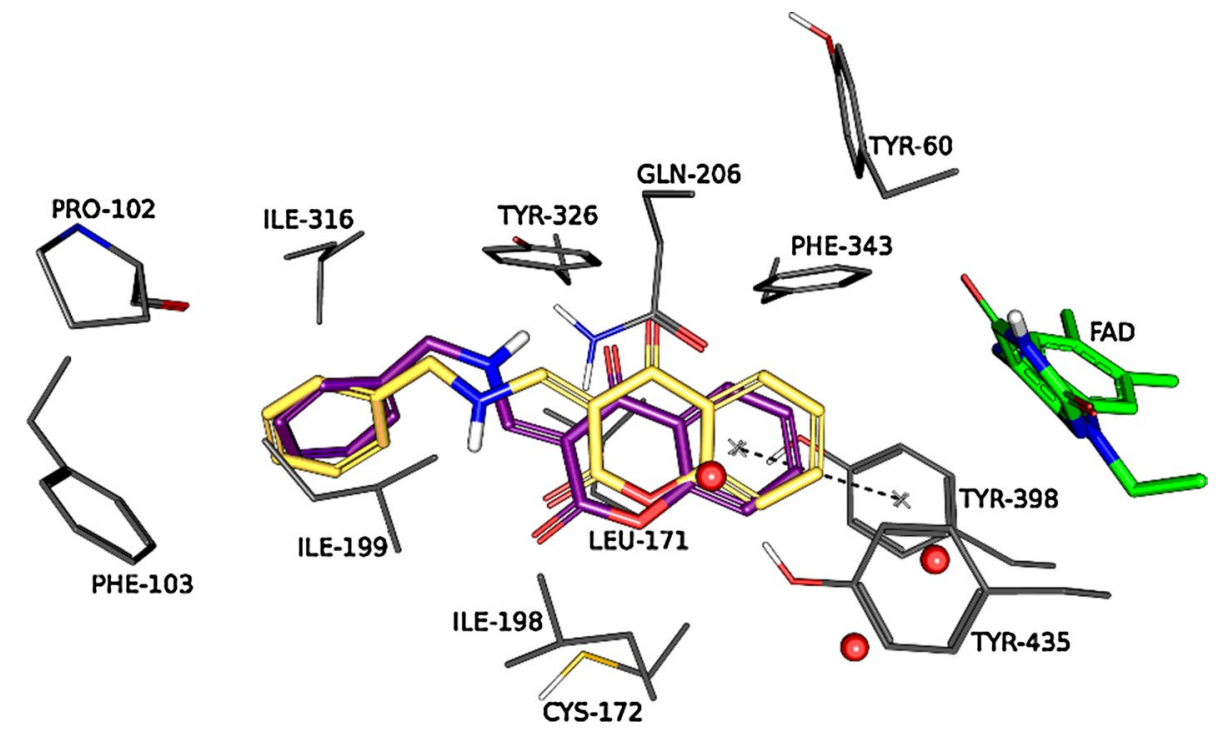

hydrogen bonding is not observed, a pi-pi stacking interaction is seen with Tyr-398, as well as a pi-sulphur interaction with Cys-172 (cis isomer). Pi-alkyl interactions between the chromane-2,4-dione and Leu-171 (both isomers) and Ile198 and Cys-172 (trans isomer) are formed, while the side chain phenyl ring is stabilised by pi-alkyl interactions with Ile-199 and Ile-316 (both isomers). Ile-199 is of further significance by establishing carbon-hydrogen bonding with a benzylic $\mathrm{H}$ of the side chain and the $\mathrm{C} 2$ carbonyl oxygen of the chromane-2,4-dione (both isomers). The phenolic oxygen of Tyr-326 also forms a carbon-hydrogen bond with the benzylic $\mathrm{H}$ (both isomers). This analysis suggests that both isomers of $\mathbf{1 4 b}$ are able to bind and interact with MAO-B, with the binding modes and interactions being very similar. It may be concluded that both isomers contribute to the observed MAO-B inhibition.

An analysis of the structure-activity relationships (SARs) for MAO-B inhibition revealed some interesting trends. While the ester derivatives are weak MAO-B inhibitors, for the chromane-2,4-diones substitution with the benzyl group appears to be appropriate for MAO-B inhibition among the compounds evaluated. In this regard, larger substituents or further substitution with chlorine on the side chain phenyl results in decreased activity. It is noteworthy that substitution with the benzyl moiety (e.g. 14b) yielded the highest potency MAO-B inhibition among the chromane-2,4-diones. This structural element is present in many experimental MAO inhibitors as well as in the clinically used agent, safinamide. Since MAO inhibition of these compounds is modest, further structural modifications will be required to optimise these compounds for further development as potent, reversible inhibitors of MAO-B. As mentioned, an interesting observation is that MAO-B inhibition decreases with side chain elongation from compound $\mathbf{1 4 b}$ to $\mathbf{1 4 c}$ and $\mathbf{1 4 d}$, with a large decrease in potency as further chain elongation occurs to yield 14e. Considering the results of the molecular docking study, it may be concluded that steric conflicts may occur between the 3-aminomethylidene side chain and the MAO-B entrance cavity, as the length of the side chain increases. A side chain linker length of 3 atoms (e.g. 14b) seems to be optimal for avoiding steric conflicts and/or maximising productive interactions with the entrance cavity. The placement of the side chain in the entrance cavity thus appears to be an important determining factor for MAO-B inhibition potency, and further enhancement of activity should focus on modification of the 3-aminomethylidene side chain and binding interactions with the entrance cavity. As outlined in the introduction, MAO-B inhibitors are useful agents in the treatment of Parkinson's disease. The chromane-2,4-diones may be particularly suitable for further development since, as exemplified by $\mathbf{1 4 b}$, they are fully reversible MAO-B inhibitors with comparatively weak MAO-A inhibition potencies. This will greatly reduce the liability for hypertensive crisis which is associated with irreversible MAO-A inhibition.

\section{Experimental section}

\section{Chemicals and instrumentation}

All reagents and chemicals were purchased from SigmaAldrich and were used without further purification. All solvents used were obtained from ACE, while deuterated solvents used for NMR spectroscopy were purchased from Merck. Routine reaction monitoring was performed by thinlayer chromatography (TLC). Silica gel 60 F254 sheets (Merck) were used for TLC with mobile phases consisting of ethyl acetate: methanol (8:2) and ethyl acetate: petroleum ether (8:2). Carbon $\left({ }^{13} \mathrm{C}\right)$ and proton $\left({ }^{1} \mathrm{H}\right)$ NMR spectra were 
recorded on a Bruker Avance III 600 spectrometer at frequencies of $150 \mathrm{MHz}$ and $600 \mathrm{MHz}$, respectively. All NMR samples were dissolved in either deuterated chloroform $\left(\mathrm{CDCl}_{3}\right)$ or deuterated dimethyl sulfoxide (DMSO- $\left.d_{6}\right)$. The chemical shifts $(\delta)$ are reported in parts per million (ppm) and coupling constants $(J)$ in $\mathrm{Hz}$. The spin multiplicities are given in abbreviated format: s (singlet), br s (broad singlet), $\mathrm{d}$ (doublet), br d (broad doublet), dd (doublet of doublets), ddd (doublet of doublet of doublets), $t$ (triplet), br $t$ (broad triplet), q (quartet), p (pentet/quintet), s (septet) or m (multiplet). Chemical shifts are referenced to the residual solvent signal, at $7.26 \mathrm{ppm}$ for ${ }^{1} \mathrm{H}$ and $77.0 \mathrm{ppm}$ for ${ }^{13} \mathrm{C}$ in $\mathrm{CDCl}_{3}$ and at $2.50 \mathrm{ppm}$ for ${ }^{1} \mathrm{H}$ and $39.5 \mathrm{ppm}$ for ${ }^{13} \mathrm{C}$ in DMSO- $d_{6}$. High-resolution mass spectra (HRMS) were recorded on a Bruker micrOTOF-Q II mass spectrometer in atmosphericpressure chemical ionisation (APCI) mode, in positive ionisation mode. Melting points were determined with a Büchi B-545 melting point apparatus and are uncorrected. An Alpha FTIR spectrometer (Bruker) was used to record IR spectra. The OPUS/Mentor software interface was used to process the spectrometer readings. Fluorescence spectrophotometry was carried out using a Varian Cary Eclipse fluorescence spectrophotometer. Microsomes from insect cells containing recombinant human MAO-A and MAO-B (5 mg protein $/ \mathrm{mL}$ ) and kynuramine dihydrobromide were obtained from Sigma-Aldrich.

\section{Purity determination by HPLC}

Purity of the synthesised compounds was determined by HPLC using an Agilent 1200 HPLC system equipped with a quaternary pump and an Agilent 1200 series diode array detector. HPLC grade acetonitrile (Merck) and Milli-Q water (Millipore) were used for the chromatography. A Venusil XBP C18 column $(4.60 \times 150 \mathrm{~mm}, 5 \mu \mathrm{m})$ was used with acetonitrile (30\%) and Milli-Q water (70\%) as the initial mobile phase at a flow rate of $1 \mathrm{~mL} / \mathrm{min}$. At the start of each injection, a solvent gradient programme was initiated by linearly increasing the composition of the acetonitrile in the mobile phase to $85 \%$ acetonitrile over a period of $5 \mathrm{~min}$. Each run lasted $15 \mathrm{~min}$ and a time period of $5 \mathrm{~min}$ was allowed for equilibration between runs. A volume of $20 \mu \mathrm{L}$ of solutions of the test compounds in acetonitrile $(1 \mathrm{mM})$ was injected into the HPLC system, and the eluent was monitored at wavelengths of 210,254 and $300 \mathrm{~nm}$.

\section{X-ray crystallography}

X-ray crystallographic studies were carried out with a Bruker SMART X2S benchtop crystallographic system. For this purpose a single colourless crystal of compound $\mathbf{1 4} \mathbf{j}$ was mounted on a MiTeGen MicroMount. Intensity measurements were taken using monochromated (doubly curved silicon crystal) Mo- $\mathrm{K}_{\alpha}$-radiation $(0.71073 \AA)$ from a sealed microfocus tube. Generator settings were $50 \mathrm{kV}, 1 \mathrm{~mA}$. APEX2 software was used for preliminary determination of the unit cell and determination of integrated intensities, and unit cell refinement was performed using Bruker SAINT. The data collection temperature was $-73^{\circ} \mathrm{C}$. Data were corrected for absorption effects with SADABS using the multiscan technique. The structure was solved with XS, and subsequent structure refinements were performed with XL. The structure was refined by anisotropic full-matrix least-squares refinement on $\mathrm{F}^{2}: \mathrm{C}_{17} \mathrm{H}_{14} \mathrm{~N}_{2} \mathrm{O}_{3}, M=294.30 \mathrm{~g} \mathrm{~mol}^{-1}$, crystal size: $0.20 \times 0.20 \times 0.60 \mathrm{~mm}^{3}$, monoclinic, space group $C 12 / c 1, a=33.050(5) \AA, b=4.9754(7) \AA, c=21.666(3)$ $\AA, \alpha=\gamma=90^{\circ}, \beta=128.152(9)^{\circ}, V=2801.6(8) \AA^{3}, Z=8$, $\rho_{\text {calcd }}=1.395 \mathrm{~g} \mathrm{~cm}^{-3}, \mu=0.096 \mathrm{~mm}^{-1}, \lambda=0.71073 \AA$, $T=200(2) \mathrm{K}, \theta_{\text {range }}=1.56-25.04^{\circ}$, reflections collected: 13307, independent: $2474\left(R_{\text {int }}=0.0338\right), 203$ parameters, final $R$ indices $[I>2 \sigma(\mathrm{I})]: R_{1}=0.0584 ; w R_{2}=0.1593, \max /$ min residual electron density: $0.468 /-0.368 \mathrm{e}^{-} / \AA^{3}$, goodness of fit on $F^{2} 1.061, \mathrm{~F}(000)=1232$. CCDC 1859532 contains the supplementary crystallographic data for this paper. The data can be obtained free of charge from The Cambridge Crystallographic Data Centre via www.ccdc.cam.ac.uk/struc tures.

\section{Procedure for synthesis of ester derivatives 12a-e}

1,1'-Carbonyldiimidazole (CDI) $(5.26 \mathrm{mmol}, 1$ equiv.) was added to a stirred suspension of chromone 3-carboxylic acid (5.26 mmol, 1 equiv.) in $N, N$-dimethylformamide (DMF) $(20 \mathrm{~mL})$. This mixture was stirred for $2-3 \mathrm{~h}$ at $60^{\circ} \mathrm{C}$ under nitrogen, after which the reaction was cooled to $0{ }^{\circ} \mathrm{C}$ and the alcohol (5.26 mmol, 1 equiv.) was added. The mixture was allowed to return to room temperature and stirred overnight. On completion, $40 \mathrm{~mL}$ of distilled water was added and the aqueous phase was extracted to ethyl acetate $(3 \times 20 \mathrm{~mL})$. This organic fraction was washed with distilled water $(5 \times 40 \mathrm{~mL})$ and brine, dried over magnesium sulphate and concentrated in vacuo. The resulting crude product was purified by recrystallisation from methanol.

Phenyl 4-oxo-4H-chromene-3-carboxylate (12a) The title compound was prepared from chromone-3-carboxylic acid and phenol in a yield of $22 \%$ : mp. $154.7-155.5{ }^{\circ} \mathrm{C}$ (methanol), pale yellow crystals. ${ }^{1} \mathrm{H}$ NMR $\left(600 \mathrm{MHz}, \mathrm{DMSO}-d_{6}\right)$ $\delta 9.26(\mathrm{~s}, 1 \mathrm{H}, \mathrm{H}-2), 8.13(\mathrm{dd}, J=7.9,1.7 \mathrm{~Hz}, 1 \mathrm{H}, \mathrm{H}-5), 7.88$ (ddd, $J=8.7,7.2,1.7 \mathrm{~Hz}, 1 \mathrm{H}, \mathrm{H}-7), 7.76(\mathrm{dd}, J=8.5,1.0 \mathrm{~Hz}$, $1 \mathrm{H}, \mathrm{H}-8), 7.58$ (ddd, $J=8.1,7.2,1.1 \mathrm{~Hz}, 1 \mathrm{H}, \mathrm{H}-6), 7.50$ 7.43 (m, 2H, H-3'/5'), 7.34-7.27 (m, 1H, H-4'), 7.28-7.22 $\left(\mathrm{m}, 2 \mathrm{H}, \mathrm{H}-2^{\prime} / 6^{\prime}\right) .{ }^{13} \mathrm{C}$ NMR (151 MHz, DMSO- $\left.d_{6}\right) \delta 172.5$ (C-4), 164.0 (C-2), 161.1 (C-9), 155.2 (C-8a), 150.2 (C-1'), 135.0 (C-7), 129.6 (C-3'/5'), 126.7 (C-6), 126.1 (C-4'), 125.5 (C-5), 124.3 (C-4a), 121.9 (C-2'/6'), 118.7 (C-8), 
114.8 (C-3). IR $\nu_{\max }\left(\mathrm{cm}^{-1}\right) 3057,1746,1645,1614,1486$, 1094, 750. APCI-HRMS $m / z$ calcd. for $\mathrm{C}_{16} \mathrm{H}_{11} \mathrm{O}_{4}, 267.0652$, $[M+H]^{+}$found 267.0658. Purity (HPLC): $81 \%$.

Benzyl 4-oxo-4H-chromene-3-carboxylate (12b) The title compound was prepared from chromone-3-carboxylic acid and benzyl alcohol in a yield of $16 \%$ : mp. $107.3-108.3{ }^{\circ} \mathrm{C}$ (methanol), pale brown crystals. ${ }^{1} \mathrm{H}$ NMR $(600 \mathrm{MHz}$, $\left.\mathrm{CDCl}_{3}\right) \delta 8.65(\mathrm{~s}, 1 \mathrm{H}, \mathrm{H}-2), 8.27(\mathrm{dd}, J=8.0,1.7 \mathrm{~Hz}, 1 \mathrm{H}$, H-5), 7.67 (ddd, $J=8.7,7.1,1.7 \mathrm{~Hz}, 1 \mathrm{H}, \mathrm{H}-7$ ), 7.48-7.40 (m, $4 \mathrm{H}, \mathrm{H}-6, \mathrm{H}-8, \mathrm{H}-2^{\prime} / 6^{\prime}$ or $\left.\mathrm{H}-3^{\prime} / 5^{\prime}\right)^{*}, 7.39-7.33$ (m, $2 \mathrm{H}$, $\mathrm{H}-2^{\prime} / 6^{\prime}$ or $\left.\mathrm{H}-3^{\prime} / 5^{\prime}\right)^{*}, 7.34-7.28$ (m, 1H, H-4'), 5.35 (s, 2H, $\mathrm{H}-10) .{ }^{13} \mathrm{C}$ NMR (151 MHz, $\left.\mathrm{CDCl}_{3}\right) \delta 173.3(\mathrm{C}-4), 163.1$ (C-9), 161.9 (C-2), 155.5 (C-8a), 135.5 (C-1'), 134.2 (C-7), $128.6\left(\mathrm{C}-2^{\prime} / 6^{\prime}\right.$ or $\left.\mathrm{C}-3^{\prime} / 5^{\prime}\right), 128.24\left(\mathrm{C}-4^{\prime}\right), 128.16\left(\mathrm{C}-2^{\prime} / 6^{\prime}\right.$ or $\left.\mathrm{C}^{-} 3^{\prime} / 5^{\prime}\right), 126.5$ (C-5 or C-6), 126.2 (C-5 or C-6), 125.1 (C-4a), 118.1 (C-8), 116.0 (C-3), $66.9(\mathrm{C}-10)$. IR $\nu_{\max }\left(\mathrm{cm}^{-1}\right)$ 3087, 1727, 1650, 1613, 1462, 1079, 754. APCI-HRMS m/z calcd. for $\mathrm{C}_{17} \mathrm{H}_{13} \mathrm{O}_{4}, 281.0808,[M+H]^{+}$found 281.0809. Purity (HPLC): $97 \%$. *In no particular order.

4-Chlorophenyl 4-oxo-4H-chromene-3-carboxylate (12c) The title compound was prepared from chromone-3-carboxylic acid and 4-chlorophenol in a yield of 21\%: mp. 181.9$182.3{ }^{\circ} \mathrm{C}$ (methanol), pale yellow crystals. ${ }^{1} \mathrm{H}$ NMR $\left(600 \mathrm{MHz}, \mathrm{CDCl}_{3}\right) \delta 8.83(\mathrm{~s}, 1 \mathrm{H}, \mathrm{H}-2), 8.29$ (dd, $J=8.0$, $1.7 \mathrm{~Hz}, 1 \mathrm{H}, \mathrm{H}-5$ ), 7.72 (ddd, $J=8.7,7.2,1.7 \mathrm{~Hz}, 1 \mathrm{H}$, H-7), 7.54-7.45 (m, 2H, H-6, H-8)*, 7.35 (d, $J=8.8 \mathrm{~Hz}$, $\left.2 \mathrm{H}, \mathrm{H}-3^{\prime} / 5^{\prime}\right), 7.16\left(\mathrm{~d}, J=8.8 \mathrm{~Hz}, 2 \mathrm{H}, \mathrm{H}-2^{\prime} / 6^{\prime}\right) .{ }^{13} \mathrm{C} \mathrm{NMR}$ $\left(151 \mathrm{MHz}, \mathrm{CDCl}_{3}\right) \delta 173.0(\mathrm{C}-4), 162.8(\mathrm{C}-2), 161.6(\mathrm{C}-9)$, 155.5 (C-8a), 148.7 (C-1'), 134.5 (C-7), 131.5 (C-4'), 129.5 $\left(\mathrm{C}-3^{\prime} / 5^{\prime}\right), 126.61,126.57$ (C-5, C-6)*, 125.0 (C-4a), 123.1 $\left(\mathrm{C}-2^{\prime} / 6^{\prime}\right), 118.2(\mathrm{C}-8), 115.3(\mathrm{C}-3)$. IR $\nu_{\max }\left(\mathrm{cm}^{-1}\right) 3056$, 1752, 1643, 1615, 1461, 1070, 758. APCI-HRMS $\mathrm{m} / \mathrm{z}$ calcd. for $\mathrm{C}_{16} \mathrm{H}_{10} \mathrm{ClO}_{4}, 301.0262,[M+H]^{+}$found 301.0268. Purity (HPLC): $83 \%$. *In no particular order.

3-Chlorophenyl 4-oxo-4H-chromene-3-carboxylate (12d) The title compound was prepared from chromone-3-carboxylic acid and 3-chlorophenol in a yield of 19\%: mp. 151.2$155{ }^{\circ} \mathrm{C}$ (methanol), yellow crystals. ${ }^{1} \mathrm{H}$ NMR $(600 \mathrm{MHz}$, DMSO- $\left.d_{6}\right) \delta 9.27(\mathrm{~s}, 1 \mathrm{H}, \mathrm{H}-2), 8.13(\mathrm{dd}, J=7.9,1.7 \mathrm{~Hz}$, $1 \mathrm{H}, \mathrm{H}-5$ ), 7.88 (ddd, $J=8.7,7.2,1.7 \mathrm{~Hz}, 1 \mathrm{H}, \mathrm{H}-7), 7.76$ (dd, $J=8.5,1.0 \mathrm{~Hz}, 1 \mathrm{H}, \mathrm{H}-8), 7.58$ (ddd, $J=8.1,7.2,1.1 \mathrm{~Hz}, 1 \mathrm{H}$, H-6), 7.50 (t, $\left.J=8.1 \mathrm{~Hz}, 1 \mathrm{H}, \mathrm{H}-5^{\prime}\right), 7.44$ (t, $J=2.1 \mathrm{~Hz}, 1 \mathrm{H}$, H-2'), 7.39 (ddd, $J=8.1,2.1,0.9 \mathrm{~Hz}, 1 \mathrm{H}, \mathrm{H}-4^{\prime}$ ), 7.26 (ddd, $\left.J=8.2,2.3,1.0 \mathrm{~Hz}, 1 \mathrm{H}, \mathrm{H}-6^{\prime}\right) .{ }^{13} \mathrm{C}$ NMR $(151 \mathrm{MHz}$, DMSO$\left.d_{6}\right) \delta 172.5(\mathrm{C}-4), 164.4(\mathrm{C}-2), 160.7(\mathrm{C}-9), 155.2(\mathrm{C}-8 \mathrm{a})$, 150.9 (C-1'), 135.1 (C-7), 133.4 (C-3'), 131.1 (C-5'), 126.8 (C-6), 126.3 (C-4'), 125.6 (C-5), 124.3 (C-4a), 122.4 (C-2'), $121.0\left(\mathrm{C}-6^{\prime}\right), 118.8(\mathrm{C}-8), 114.4(\mathrm{C}-3)$. IR $\nu_{\max }\left(\mathrm{cm}^{-1}\right) 3072$, $1738,1642,1615,1462,1088,755$. APCI-HRMS $m / z$ calcd. for $\mathrm{C}_{16} \mathrm{H}_{10} \mathrm{ClO}_{4}, 301.0262,[M+H]^{+}$found 301.0272. Purity: sample decomposed upon standing and purity was thus deemed acceptable based on NMR.

(4-Chlorophenyl)methyl 4-oxo-4H-chromene-3-carboxylate (12e) The title compound was prepared from chromone3-carboxylic acid and 4-chlorobenzyl-alcohol in a yield of 59\%: mp. $116.6-117.7{ }^{\circ} \mathrm{C}$ (methanol), yellow crystals. ${ }^{1} \mathrm{H}$ NMR (600 MHz, DMSO- $\left.d_{6}\right) \delta 9.00(\mathrm{~s}, 1 \mathrm{H}, \mathrm{H}-2), 8.09$ (dd, $J=8.0,1.7 \mathrm{~Hz}, 1 \mathrm{H}, \mathrm{H}-5), 7.83$ (ddd, $J=8.6,7.1,1.7 \mathrm{~Hz}$, $1 \mathrm{H}, \mathrm{H}-7$ ), 7.70 (br d, $J=8.4,1 \mathrm{H}, \mathrm{H}-8), 7.57-7.49$ (m, $3 \mathrm{H}$, H-6, H-2'/6' or H-3'/5'), 7.45 (d, $J=8.4 \mathrm{~Hz}, 2 \mathrm{H}, \mathrm{H}-2^{\prime} / 6^{\prime}$ or H-3'/5'), 5.29 (s, 2H, H-10). ${ }^{13} \mathrm{C}$ NMR (151 MHz, DMSO$\left.d_{6}\right) \delta 172.5(\mathrm{C}-4), 162.9(\mathrm{C}-2), 162.6(\mathrm{C}-9), 155.2(\mathrm{C}-8 \mathrm{a})$, $135.0\left(\mathrm{C}-1^{\prime}\right), 134.8(\mathrm{C}-7), 132.6\left(\mathrm{C}-4^{\prime}\right), 129.6\left(\mathrm{C}-2^{\prime} / 6^{\prime}\right.$ or C-3'/5'), $128.4\left(\mathrm{C}-2^{\prime} / 6^{\prime}\right.$ or C-3'/5'), $126.5(\mathrm{C}-6), 125.5(\mathrm{C}-5)$, 124.4 (C-4a), 118.6 (C-8), 115.5 (C-3), 65.2 (C-10). IR $\nu_{\max }$ $\left(\mathrm{cm}^{-1}\right): 3080,1732,1647,1614,1461,1083,766$. APCIHRMS $m / z$ calcd. for $\mathrm{C}_{17} \mathrm{H}_{12} \mathrm{ClO}_{4}, 315.0419[M+H]^{+}$found 315.0388. Purity (HPLC): $97 \%$.

\section{Procedure for synthesis of 3-aminomethylidene-2,4-chromandiones $14 a-j$}

CDI (5.26 mmol, 1 equiv.) was added to a stirred suspension of chromone 3 -carboxylic acid (5.26 mmol, 1 equiv.) in $20 \mathrm{~mL}$ DMF. This mixture was stirred for $2-3 \mathrm{~h}$ at $60^{\circ} \mathrm{C}$ under nitrogen, after which the reaction was cooled to $0{ }^{\circ} \mathrm{C}$ and the amine (5.26 mmol, 1 equiv.) was added. The mixture was allowed to return to room temperature and stirred overnight. On completion of the reaction, $40 \mathrm{~mL}$ of distilled water was added and the aqueous phase was extracted to ethyl acetate $(3 \times 20 \mathrm{~mL})$. This organic fraction was washed with distilled water $(5 \times 40 \mathrm{~mL})$ and brine, dried over magnesium sulphate and concentrated in vacuo. The resulting crude product was purified by recrystallisation from methanol.

(3E/Z)-3-[(Phenylamino)methylidene]-3,4-dihydro-2H-1-benzopyran-2,4-dione (14a) The title compound was prepared from chromone-3-carboxylic acid and aniline in a yield of 62\%: mp. 206.7-209.5 ${ }^{\circ} \mathrm{C}$ (methanol), (lit. $208-210{ }^{\circ} \mathrm{C}$, [41]; 204-208 ${ }^{\circ} \mathrm{C}$; [55], 201-202 ${ }^{\circ} \mathrm{C}$ (DMSO), [42]; 194 $236{ }^{\circ} \mathrm{C}\left(\mathrm{CHCl}_{3}\right.$ - petroleum ether), [45]), yellow fluffy crystals. Ratio of major isomer: minor isomer 1:0.9. ${ }^{1} \mathrm{H}$ NMR $\left(600 \mathrm{MHz}, \mathrm{CDCl}_{3}\right) \delta$ Major isomer: $13.68(\mathrm{~d}, J=13.5 \mathrm{~Hz}$, $1 \mathrm{H}, \mathrm{NH}), 8.88(\mathrm{~d}, J=13.6 \mathrm{~Hz}, 1 \mathrm{H}, \mathrm{H}-9), 8.05(\mathrm{dd}, J=7.8$, $1.7 \mathrm{~Hz}, 1 \mathrm{H}, \mathrm{H}-5), 7.62-7.55$ (m, 1H, H-7), 7.49-7.42 (m, $2 \mathrm{H}, \mathrm{H}-2^{\prime} / 6^{\prime}$ or $\left.\mathrm{H}-3^{\prime} / 5^{\prime}\right), 7.39-7.22$ (m, 5H, H-2'/6' or H-3'/5', H-4', H-6, H-8). Minor isomer: 11.92 (d, $J=14.4 \mathrm{~Hz}, 1 \mathrm{H}$, NH), 9.02 (d, $J=14.5 \mathrm{~Hz}, 1 \mathrm{H}, \mathrm{H}-9), 8.12$ (dd, $J=7.8$, $1.7 \mathrm{~Hz}, 1 \mathrm{H}, \mathrm{H}-5), 7.62-7.55$ (m, 1H, H-7), 7.49-7.42 (m, $2 \mathrm{H}, \mathrm{H}-2^{\prime} / 6^{\prime}$ or $\left.\mathrm{H}-3^{\prime} / 5^{\prime}\right), 7.39-7.22\left(\mathrm{~m}, 5 \mathrm{H}, \mathrm{H}-2^{\prime} / 6^{\prime}\right.$ or H-3'/5', H-4', H-6, H-8). ${ }^{13} \mathrm{C}$ NMR (151 MHz, $\left.\mathrm{CDCl}_{3}\right) \delta$ 
Major isomer: 181.8 (C-4), 163.6 (C-2), 154.95 (C-8a), 154.92 (C-9), 137.7 (C-1'), 134.8 (C-7), 130.18 (C-3'/5'), 127.5 (C-4'), 126.6 (C-5), 124.2 (C-6), 120.3 (C-4a), 118.45 (C-2'/6'), 117.43 (C-8), 98.7 (C-3). Minor isomer: 178.6 (C-4), 165.2 (C-2), 154.7 (C-8a), 153.4 (C-9), 137.7 (C-1'), 134.7 (C-7), $130.16\left(\mathrm{C}-3^{\prime} / 5^{\prime}\right), 127.4\left(\mathrm{C}-4^{\prime}\right), 125.8$ (C-5), 124.4 (C-6), 120.6 (C-4a), $118.51\left(\mathrm{C}-2^{\prime} / 6^{\prime}\right), 117.37$ (C-8), $98.8(\mathrm{C}-3)$. IR $\nu_{\max }\left(\mathrm{cm}^{-1}\right) 3180,1684,1594,1567,755$. APCI-HRMS $m / z$ calcd. for $\mathrm{C}_{16} \mathrm{H}_{12} \mathrm{NO}_{3}, 266.0812,[M+H]^{+}$ found 266.0807. Purity (HPLC): $90 \%$.

(3E/Z)-3-[(Benzylamino)methylidene]-3,4-dihydro-2H-1-benzopyran-2,4-dione (14b) The title compound was prepared from chromone-3-carboxylic acid and benzylamine in a yield of 58\%: mp. 163.8-164.6 ${ }^{\circ} \mathrm{C}$ (methanol), (lit. 165$167{ }^{\circ} \mathrm{C}$, [41]), pink crystals. Ratio of major isomer: minor isomer 1:0.3. ${ }^{1} \mathrm{H}$ NMR $\left(600 \mathrm{MHz}\right.$, DMSO- $\left.d_{6}\right) \delta$ Major isomer: $11.96-11.88(\mathrm{~m}, 1 \mathrm{H}, \mathrm{NH}), 8.62(\mathrm{~d}, J=14.6 \mathrm{~Hz}, 1 \mathrm{H}$, $\mathrm{H}-9), 7.89$ (dd, $J=7.8,1.4 \mathrm{~Hz}, 1 \mathrm{H}, \mathrm{H}-5), 7.67-7.58$ (m, $1 \mathrm{H}, \mathrm{H}-7$ ), 7.44-7.23 (m, 7H, H-6, H-8, H-2'-6' $)^{*}, 4.82$ (d, $J=6.2 \mathrm{~Hz}, 2 \mathrm{H}, \mathrm{H}-10)$. Minor isomer: $10.71-10.65(\mathrm{~m}, 1 \mathrm{H}$, $\mathrm{NH}), 8.72(\mathrm{~d}, J=15.4 \mathrm{~Hz}, 1 \mathrm{H}, \mathrm{H}-9), 7.93(\mathrm{br} \mathrm{d}, J=7.7 \mathrm{~Hz}$, $1 \mathrm{H}, \mathrm{H}-5), 7.67-7.58(\mathrm{~m}, 1 \mathrm{H}, \mathrm{H}-7), 7.44-7.23(\mathrm{~m}, 7 \mathrm{H}$, H-6, H-8, H-2'-6')*, 4.82 (d, $J=6.2 \mathrm{~Hz}, 2 \mathrm{H}, \mathrm{H}-10) .{ }^{13} \mathrm{C}$ NMR $\left(151 \mathrm{MHz}, \mathrm{DMSO}-d_{6}\right) \delta$ Major isomer: $179.4(\mathrm{C}-4)$, 162.7 (C-2), 162.2 (C-9), 154.2 (C-8a), 136.7 (C-1'), 134.3 (C-7), $128.8\left(\mathrm{C}-2^{\prime} / \mathrm{C}-6^{\prime}\right.$ or C-3'/C-5'), $128.0\left(\mathrm{C}-2^{\prime} / \mathrm{C}-6^{\prime}\right.$ or C-3'/C-5'), 127.98 (C-4'), 125.3 (C-5), 123.9 (C-6), 120.2 (C-4a), 116.9 (C-8), 96.0 (C-3), 53.2 (C-10). Minor isomer: 177.1 (C-4), 163.2 (C-2), 160.6 (C-9), 154.1 (C-8a), 137.0 (C-1'), $134.4(\mathrm{C}-7), 128.8\left(\mathrm{C}-2^{\prime} / \mathrm{C}-6^{\prime}\right.$ or $\left.\mathrm{C}^{-3} 3^{\prime} / \mathrm{C}-5^{\prime}\right), 128.0$ (C-2'/C-6' or C-3'/C-5'), 127.9 (C-4'), 125.8 (C-5), 124.0 (C-6), 120.4 (C-4a), 117.0 (C-8), 95.9 (C-3), 53.1 (C-10). IR $\nu_{\max }\left(\mathrm{cm}^{-1}\right) 3033,1708,1592,1463,746$. APCI-HRMS $\mathrm{m} / \mathrm{z}$ calcd. for $\mathrm{C}_{17} \mathrm{H}_{14} \mathrm{NO}_{3}, 280.0968,[M+H]^{+}$found 280.0972 . Purity (HPLC): 100\%. *In no particular order.

(3E/Z)-3-\{[(2-Phenylethyl)amino]methylidene\}-3,4-dihydro-2H-1-benzopyran-2,4-dione (14c) The title compound was prepared from chromone-3-carboxylic acid and phenethylamine in a yield of 59\%: $\mathrm{mp} .178 .2-178.7^{\circ} \mathrm{C}$ (methanol), white crystals. Ratio of major isomer: minor isomer 1:0.5. ${ }^{1} \mathrm{H}$ NMR $\left(600 \mathrm{MHz}\right.$, DMSO- $\left.d_{6}\right) \delta$ Major isomer: 11.68 $11.62(\mathrm{~m}, 1 \mathrm{H}, \mathrm{NH}), 8.34$ (d, J=14.3 Hz, 1H, H-9), 7.90 (dd, $J=7.7,1.7 \mathrm{~Hz}, 1 \mathrm{H}, \mathrm{H}-5), 7.66-7.59$ (m, 1H, H-7), 7.33-7.17 (m, 7H, H-2'-6', H-8, H-6)*, 3.83 (q, J=6.7 Hz, 2H, H-10), 2.96 (t, $J=7.2 \mathrm{~Hz}, 2 \mathrm{H}, \mathrm{H}-11$ ). Minor isomer: 10.40 (br s, $1 \mathrm{H}, \mathrm{NH}), 8.45$ (d, $J=14.8 \mathrm{~Hz}, 1 \mathrm{H}, \mathrm{H}-9), 7.90$ (dd, $J=7.7$, $1.7 \mathrm{~Hz}, 1 \mathrm{H}, \mathrm{H}-5), 7.66-7.59$ (m, 1H, H-7), 7.33-7.17 (m, $\left.7 \mathrm{H}, \mathrm{H}-2^{\prime}-6^{\prime}, \mathrm{H}-8, \mathrm{H}-6\right)^{*}, 3.83$ (q, J=6.7 Hz, 2H, H-10), 2.96 $(\mathrm{t}, J=7.2 \mathrm{~Hz}, 2 \mathrm{H}, \mathrm{H}-11) .{ }^{13} \mathrm{C}$ NMR $\left(151 \mathrm{MHz}, \mathrm{DMSO}-d_{6}\right) \delta$ Major isomer: 179.3 (C-4), 162.7 (C-2), 162.2 (C-9), 154.2 (C-8a), 137.9 (C-1'), 134.3 (C-7), 128.9, 128.5 (C-2'/6',
C-3'/5')*, $126.6\left(\mathrm{C}-4^{\prime}\right), 125.3(\mathrm{C}-5), 123.95$ (C-6), 120.3 (C-4a), 116.9 (C-8), 95.6 (C-3), 51.6 (C-10), 35.8 (C-11). Minor isomer: 177.0 (C-4), 163.2 (C-2), 160.6 (C-9), 154.1 (C-8a), 137.9 (C-1'), 134.4 (C-7), 128.9, 128.5 (C-2'/6', C-3'/5')*, $126.6\left(\mathrm{C}-4^{\prime}\right), 125.8$ (C-5), 124.04 (C-6), 120.4 (C-4a), 117.0 (C-8), 95.3 (C-3), 51.7 (C-10), 35.9 (C-11). IR $\nu_{\max }\left(\mathrm{cm}^{-1}\right) 3063,1708,1590,1463,741$. APCI-HRMS m/z calcd. for $\mathrm{C}_{18} \mathrm{H}_{16} \mathrm{NO}_{3}, 294.1125,[M+H]^{+}$found 294.1129. Purity (HPLC): $100 \%$. *In no particular order.

(3E/Z)-3-\{[(3-Phenylpropyl)amino]methylidene\}-3,4-dihydro-2H-1-benzopyran-2,4-dione (14d) The title compound was prepared from chromone-3-carboxylic acid and 3-phenyl-1-propylamine in a yield of 58\%: mp. $171.3-171.6{ }^{\circ} \mathrm{C}$ (methanol), white crystals. Ratio of major isomer: minor isomer 1:0.7. ${ }^{1} \mathrm{H}$ NMR $\left(600 \mathrm{MHz}\right.$, DMSO- $\left.d_{6}\right) \delta$ Major isomer: $11.76-11.57(\mathrm{~m}, 1 \mathrm{H}, \mathrm{NH}), 8.44(\mathrm{~d}, J=14.7 \mathrm{~Hz}, 1 \mathrm{H}$, H-9), 7.96-7.89 (m, 1H, H-5), 7.68-7.61 (m, 1H, H-7), 7.40-7.08 (m, 7H, H-6, H-8, H-2'-6')*, 3.60 (q, $J=6.8 \mathrm{~Hz}$, $2 \mathrm{H}, \mathrm{H}-10$ ), 2.64-2.57 (m, 2H, H-12), 1.95 (p, $J=7.3 \mathrm{~Hz}$, 2H, H-11). Minor isomer: $10.52-10.21(\mathrm{~m}, 1 \mathrm{H}, \mathrm{NH}), 8.55$ (d, $J=15.5 \mathrm{~Hz}, 1 \mathrm{H}, \mathrm{H}-9), 7.96-7.89$ (m, 1H, H-5), 7.68-7.61 (m, 1H, H-7), 7.40-7.08 (m, 7H, H-6, H-8, H-2'-6'), 3.60 (q, $J=6.8 \mathrm{~Hz}, 2 \mathrm{H}, \mathrm{H}-10), 2.64-2.57$ (m, 2H, H-12), 1.95 (p, $J=7.3 \mathrm{~Hz}, 2 \mathrm{H}, \mathrm{H}-11) .{ }^{13} \mathrm{C}$ NMR $\left(151 \mathrm{MHz}\right.$, DMSO- $\left.d_{6}\right) \delta$ Major isomer: 179.3 (C-4), 162.7 (C-2), 162.2 (C-9), 154.2 (C-8a), 140.9 (C-1'), 134.28 (C-7), 128.4, 128.3 (C-2'/6', C-3'/5')*, $125.9\left(\mathrm{C}-4^{\prime}\right), 125.3$ (C-5), 123.9 (C-6), 120.3 (C-4a), 116.9 (C-8), 95.7 (C-3), 50.0 (C-10), 31.9 (C-12), 31.15 (C-11). Minor isomer: $177.1(\mathrm{C}-4)^{* *}, 163.5(\mathrm{C}-2)$, 160.6 (C-9), 154.2 (C-8a), 140.9 (C-1'), 134.33 (C-7), 128.4, $128.3\left(\mathrm{C}-2^{\prime} / 6^{\prime}, \mathrm{C}-3^{\prime} / 5^{\prime}\right)^{*}, 125.7$ (C-4'), 125.3 (C-5), 124.0 (C-6), 120.5 (C-4a), 117.0 (C-8), 95.7 (C-3), 50.2 (C-10), 31.9 (C-12), 31.2 (C-11). IR $\nu_{\max }\left(\mathrm{cm}^{-1}\right) 3023,1711$, 1603, 1462, 752. APCI-HRMS $\mathrm{m} / z$ calcd. for $\mathrm{C}_{19} \mathrm{H}_{18} \mathrm{NO}_{3}$, 308.1281, $[M+H]^{+}$found 308.1280. Purity (HPLC): $100 \%$ * In no particular order. **Shift based on HMBC correlation, signal not visible on ${ }^{13} \mathrm{C}$ NMR.

(3E/Z)-3-\{[(4-Phenylbutyl)amino]methylidene\}-3,4-dihydro-2H-1-benzopyran-2,4-dione (14e) The title compound was prepared from chromone-3-carboxylic acid and 4-phenylbutylamine in a yield of $13 \%$ : mp. $142.4-143.3{ }^{\circ} \mathrm{C}$ (methanol), white crystals. Ratio of major isomer: minor isomer 1:0.4. ${ }^{1} \mathrm{H}$ NMR $\left(600 \mathrm{MHz}, \mathrm{CDCl}_{3}\right) \delta$ Major isomer: 11.86 (br s, 1H, NH), 8.34 (d, $J=14.1 \mathrm{~Hz}, 1 \mathrm{H}, \mathrm{H}-9), 7.99$ (dd, $J=7.8,1.7 \mathrm{~Hz}, 1 \mathrm{H}, \mathrm{H}-5), 7.54(\mathrm{ddd}, J=8.4,7.4,1.7 \mathrm{~Hz}$, 1H, H-7), 7.30-7.12 (m, 7H, H-6, H-8, H-2'-H-6')*, 3.50 (q, $J=6.4 \mathrm{~Hz}, 2 \mathrm{H}, \mathrm{H}-10), 2.65(\mathrm{t}, J=6.8 \mathrm{~Hz}, 2 \mathrm{H}, \mathrm{H}-13$ ), 1.79-1.66 (m, 4H, H-11, H-12)*. Minor isomer: 10.21 (br s, $1 \mathrm{H}, \mathrm{NH}), 8.50(\mathrm{~d}, J=14.9 \mathrm{~Hz}, 1 \mathrm{H}, \mathrm{H}-9), 8.07$ (dd, J = 7.8, $1.6 \mathrm{~Hz}, 1 \mathrm{H}, \mathrm{H}-5), 7.57-7.53$ (m, 1H, H-7), 7.30-7.12 (m, $\left.7 \mathrm{H}, \mathrm{H}-6, \mathrm{H}-8, \mathrm{H}-2^{\prime}-\mathrm{H}^{-} 6^{\prime}\right)^{*}, 3.52$ (q, $J=6.4 \mathrm{~Hz}, 2 \mathrm{H}, \mathrm{H}-10$ ), 
$2.65(\mathrm{t}, J=6.8 \mathrm{~Hz}, 2 \mathrm{H}, \mathrm{H}-13), 1.79-1.66(\mathrm{~m}, 4 \mathrm{H}, \mathrm{H}-11$, $\mathrm{H}-12) * .{ }^{13} \mathrm{C}$ NMR $\left(151 \mathrm{MHz}, \mathrm{CDCl}_{3}\right) \delta$ Major isomer: 181.3 (C-4), 163.9 (C-2), 162.2 (C-9), 154.8 (C-8a), 141.08 (C-1'), 134.2 (C-7), 128.5, $128.3\left(\mathrm{C}-2^{\prime} / 6^{\prime}, \mathrm{C}^{\prime} 3^{\prime} / 5^{\prime}\right) * 126.1$ (C-5), 125.6 (C-4'), 123.9 (C-6), 120.5 (C-4a), 117.3 (C-8), 96.83 (C-3), 50.9 (C-10), 35.2 (C-13), 29.57, 28.0 (C-11, C-12)*. Minor isomer: 178.4 (C-4), 165.2 (C-2), 160.6 (C-9), 154.6 (C-8a), 141.10 (C-1'), 134.3 (C-7), 128.5, 128.3 (C-2'/6', C-3'/5')*, $126.3(\mathrm{C}-5), 125.6\left(\mathrm{C}-4^{\prime}\right), 124.1$ (C-6), 120.7 (C-4a), 117.2 (C-8), 96.76 (C-3), 50.8 (C-10), 35.2 (C-13), 29.64, $28.0(\mathrm{C}-11, \mathrm{C}-12)^{*}$. IR $\nu_{\max }\left(\mathrm{cm}^{-1}\right) 3195,1687$, $1606,1463,754$. APCI-HRMS $m / z$ calcd. for $\mathrm{C}_{20} \mathrm{H}_{20} \mathrm{NO}_{3}$, $322.1438,[M+H]^{+}$found 322.1445 . Purity (HPLC): $100 \%$. *In no particular order.

(3E/Z)-3-\{[(4-Chlorophenyl)amino]methylidene\}-3,4-dihydro-2H-1-benzopyran-2,4-dione (14f) The title compound was prepared from chromone-3-carboxylic acid and 4-chloroaniline in a yield of $57 \%$ : mp. $251.7-252.7{ }^{\circ} \mathrm{C}$ (methanol), (lit. $250{ }^{\circ} \mathrm{C}$, [56]), yellow solid. Ratio of major isomer: minor isomer 1:0.4. ${ }^{1} \mathrm{H}$ NMR $\left(600 \mathrm{MHz}\right.$, DMSO- $\left.d_{6}\right) \delta$ Major isomer: $13.37(\mathrm{~d}, J=13.8 \mathrm{~Hz}, 1 \mathrm{H}, \mathrm{NH}), 8.84(\mathrm{~d}, J=13.8 \mathrm{~Hz}$, 1H, H-9), 8.00-7.95 (m, 1H, H-5), 7.74-7.67 (m, 3H, H-7, H-2'/6'), 7.56-7.49 (m, 2H, H-3'/5'), 7.39-7.30 (m, 2H, H-6, $\mathrm{H}-8)^{*}$. Minor isomer: $11.83(\mathrm{~d}, J=14.5 \mathrm{~Hz}, 1 \mathrm{H}, \mathrm{NH}), 8.86$ (d, $J=14.8 \mathrm{~Hz}, 1 \mathrm{H}, \mathrm{H}-9), 8.00-7.95$ (m, 1H, H-5), 7.74-7.67 (m, 3H, H-7, H-2'/6'), 7.56-7.49 (m, 2H, H-3'/5'), 7.39$7.30(\mathrm{~m}, 2 \mathrm{H}, \mathrm{H}-6, \mathrm{H}-8) * .{ }^{13} \mathrm{C}$ NMR (151 MHz, DMSO- $\left.d_{6}\right)$ $\delta$ Major isomer: $180.3(\mathrm{C}-4), 162.3(\mathrm{C}-2), 155.8(\mathrm{C}-9)$, 154.4 (C-8a), 137.1 (C-1'), 135.1 (C-7), 131.2 (C-4'), 129.6 (C-3'/5'), 125.5 (C-5), 124.4 (C-6), 121.3 (C-2'/6'), 119.9 (C-4a), 117.2 (C-8), 98.3 (C-3). Minor isomer: 177.5 (C-4), 163.1 (C-2), 154.5 (C-9), 154.2 (C-8a), 137.6 (C-1'), 135.0 (C-7), 131.1 (C-4'), 129.5 (C-3'/5'), 125.9 (C-5), 124.5 (C-6), 121.7 (C-2'/6'), 120.2 (C-4a), 117.3 (C-8), 98.2 (C-3). IR $\nu_{\max }\left(\mathrm{cm}^{-1}\right) 3076,1711,1614,1463,750$. APCI-HRMS $m / z$ calcd. for $\mathrm{C}_{16} \mathrm{H}_{11} \mathrm{ClNO}_{3}, 300.0422,[M+H]^{+}$found 300.0439. Purity (HPLC): 79\%. *In no particular order.

(3E/Z)-3-(\{[(4-Chlorophenyl)methyl]amino $\}$ methylidene)-3,4-dihydro-2H-1-benzopyran-2,4-dione (14g) The title compound was prepared from chromone3-carboxylic acid and 4-chlorobenzylamine in a yield of 37\%: mp. $182.7-183.1^{\circ} \mathrm{C}$ (methanol), white crystals. Ratio of major isomer: minor isomer 1:0.5. ${ }^{1} \mathrm{H}$ NMR $(600 \mathrm{MHz}$, DMSO- $\left.d_{6}\right) \delta$ Major isomer: 11.87 (br s, $\left.1 \mathrm{H}, \mathrm{NH}\right), 8.61$ (br s, 1H, H-9), 7.95-7.86 (m, 1H, H-5), 7.67-7.60 (m, 1H, H-7), 7.48-7.38 (m, 4H, H-2'/6', H-3'/5')*, 7.32-7.23 (m, 2H, H-6, $\mathrm{H}-8), 4.80$ (s, 2H, H-10). Minor isomer: $10.66(\mathrm{br} \mathrm{s}, 1 \mathrm{H}$, $\mathrm{NH}), 8.71$ (br s, 1H, H-9), 7.95-7.86 (m, 1H, H-5), 7.67$7.60(\mathrm{~m}, 1 \mathrm{H}, \mathrm{H}-7), 7.48-7.38$ (m, 4H, H-2 $\left./ 6^{\prime}, \mathrm{H}-3^{\prime} / 5^{\prime}\right) *$, $7.32-7.23$ (m, 2H, H-6, H-8), 4.80 (s, 2H, H-10). ${ }^{13} \mathrm{C} \mathrm{NMR}$ $\left(151 \mathrm{MHz}, \mathrm{DMSO}-d_{6}\right) \delta$ Major isomer: 179.5 (C-4), 162.8
(C-2), 162.3 (C-9), 154.3 (C-8a), 135.9 (C-1'), 134.5 (C-7), $132.7\left(\mathrm{C}-4^{\prime}\right), 130.0,128.8\left(\mathrm{C}-2^{\prime} / 6^{\prime}, \mathrm{C}-3^{\prime} / 5^{\prime}\right) *, 125.3(\mathrm{C}-5)$, 124.0 (C-6), 120.3 (C-4a), 117.0 (C-8), 96.2 (C-3), 52.5 (C-10). Minor isomer: 177.3 (C-4), 163.2 (C-2), 160.8 (C-9), 154.3 (C-8a), 136.1 (C-1'), 134.5 (C-7), 132.7 (C-4'), 130.0, $128.8\left(\mathrm{C}-2^{\prime} / 6^{\prime}, \mathrm{C}-3^{\prime} / 5^{\prime}\right) *, 125.8(\mathrm{C}-5), 124.1(\mathrm{C}-6), 120.4$ (C-4a), 117.1 (C-8), 96.0 (C-3), 52.5 (C-10). IR $\nu_{\max }\left(\mathrm{cm}^{-1}\right)$ $3183,1698,1617,1464,753$. APCI-HRMS $m / z$ calcd. for $\mathrm{C}_{17} \mathrm{H}_{13} \mathrm{ClNO}_{3}, 314.0578,[M+H]^{+}$found 314.0557 . Purity (HPLC): $100 \% . *$ In no particular order.

(3E/Z)-3-(\{[2-(3-Chlorophenyl)ethyl]amino\} methylidene)-3,4-dihydro-2H-1-benzopyran-2,4-dione (14h) The title compound was prepared from chromone3-carboxylic acid and 2-(3-chlorophenyl)ethan-1-amine in a yield of $70 \%$ : mp. $216.3-217.6{ }^{\circ} \mathrm{C}$ (methanol), white fluffy crystals. The ratio of major isomer: minor isomer $1: 0.5 .{ }^{1} \mathrm{H}$ NMR $\left(600 \mathrm{MHz}\right.$, DMSO- $\left.d_{6}\right) \delta$ Major isomer: $10.45-10.35$ (m, 1H, NH), 8.37 (d, $J=14.6 \mathrm{~Hz}, 1 \mathrm{H}, \mathrm{H}-9), 7.94-7.88$ (m, 1H, H-5), 7.68-7.60 (m, 1H, H-7), 7.39-7.18 (m, 6H, H-2',H-4', H-5', H-6', H-6, H-8), 3.83 (q, J=7.0 Hz, 2H, H-10), 3.01-2.94 (m, 2H, H-11). Minor isomer: 11.66-11.61 (m, $1 \mathrm{H}, \mathrm{NH}), 8.48(\mathrm{~d}, J=15.5 \mathrm{~Hz}, 1 \mathrm{H}, \mathrm{H}-9), 7.94-7.88$ (m, 1H, H-5), 7.68-7.60 (m, 1H, H-7), 7.39-7.18 (m, 6H, H-2',H-4', H-5', H-6', H-6, H-8), 3.83 (q, $J=7.0$ Hz, 2H, $\mathrm{H}-10), 3.01-2.94$ (m, 2H, H-11). ${ }^{13} \mathrm{C}$ NMR (151 MHz, DMSO- $\left.d_{6}\right) \delta$ Major isomer: 179.3 (C-4), 162.7 (C-2), 162.3 (C-9), 154.2 (C-8a), 140.5 (C-1'), 134.3 (C-7), 133.1 (C-3'), 130.3, 128.9, 127.7, 126.6 (C-2', C-4', C-5', C-6')*, 125.3 (C-5), 124.0 (C-6) 120.3 (C-4a), 116.9 (C-8), 95.6 (C-3), 51.2 (C-10), 35.3 (C-11). Minor isomer: 177.0 (C-4), 163.2 (C-2), 160.7 (C-9), 154.1 (C-8a), 140.5 (C-1'), 134.4 (C-7), 133.1 (C-3'), 130.3, 128.9, 127.7, 126.5 (C-2', C-4', C-5', C-6')*, 125.8 (C-5), 124.1 (C-6), 120.3 (C-4a), 117.0 (C-8), 95.4 (C-3), $51.3(\mathrm{C}-10), 35.3(\mathrm{C}-11)$. IR $\nu_{\max }\left(\mathrm{cm}^{-1}\right)$ 3140, 1705, 1623, 1464, 752. APCI-HRMS $\mathrm{m} / \mathrm{z}$ calcd. for $\mathrm{C}_{18} \mathrm{H}_{15} \mathrm{ClNO}_{3}, 328.0735,[M+H]^{+}$found 328.0734 . Purity (HPLC): 98\%. *In no particular order.

(3E/Z)-3-\{[(Pyridin-2-yl)amino]methylidene\}-3,4-dihydro-2H-1-benzopyran-2,4-dione (14i) The title compound was prepared from chromone-3-carboxylic acid and 2-aminopyridine in a yield of $65 \%$ : mp. $212.2-214.9^{\circ} \mathrm{C}$ (methanol), (lit. 237-240 ${ }^{\circ} \mathrm{C}$ (DMF), [47]), yellow solid. Ratio of major isomer: minor isomer 1:0.4. ${ }^{1} \mathrm{H}$ NMR $(600 \mathrm{MHz}$, $\left.\mathrm{CDCl}_{3}\right) \delta$ Major isomer: $13.57(\mathrm{~d}, J=12.5 \mathrm{~Hz}, 1 \mathrm{H}, \mathrm{NH})$, 9.61 (d, $J=12.8 \mathrm{~Hz}, 1 \mathrm{H}, \mathrm{H}-9), 8.49-8.43$ (m, 1H, H-6'), 8.05 (dd, $J=7.8,1.7 \mathrm{~Hz}, 1 \mathrm{H}, \mathrm{H}-5), 7.77$ (ddd, $J=8.1,7.4,1.9 \mathrm{~Hz}$, 1H, H-4'), 7.63-7.56 (m, 1H, H-7), 7.32-7.23 (m, 2H, H-6, H-8), 7.20 (ddd, $J=7.4,4.8,0.9 \mathrm{~Hz}, 1 \mathrm{H}, \mathrm{H}-5^{\prime}$ ), 7.10 (br d, $\left.J=8.1 \mathrm{~Hz}, 1 \mathrm{H}, \mathrm{H}-3^{\prime}\right)$. Minor isomer: $11.91(\mathrm{~d}, J=13.7 \mathrm{~Hz}$, $1 \mathrm{H}, \mathrm{NH}), 9.71$ (d, $J=13.7 \mathrm{~Hz}, 1 \mathrm{H}, \mathrm{H}-9), 8.49-8.43(\mathrm{~m}, 1 \mathrm{H}$, H-6'), 8.13 (dd, $J=7.8,1.7 \mathrm{~Hz}, 1 \mathrm{H}, \mathrm{H}-5), 7.77$ (ddd, $J=8.1$, 
7.4, $\left.1.9 \mathrm{~Hz}, 1 \mathrm{H}, \mathrm{H}-4^{\prime}\right), 7.63-7.56$ (m, 1H, H-7), 7.32-7.23 (m, 2H, H-6, H-8), 7.20 (ddd, $J=7.4,4.8,0.9 \mathrm{~Hz}, 1 \mathrm{H}, \mathrm{H}-5^{\prime}$ ), 7.12 (br d, $\left.J=8.1 \mathrm{~Hz}, 1 \mathrm{H}, \mathrm{H}-3^{\prime}\right) .{ }^{13} \mathrm{C}$ NMR $(151 \mathrm{MHz}$, $\left.\mathrm{CDCl}_{3}\right) \delta$ Major isomer: $182.4(\mathrm{C}-4), 163.3(\mathrm{C}-2), 155.1$ (C-9), 154.4 (C-8a), 149.4 (C-6'), 149.1 (C-2'), 139.0 (C-4'), 135.1 (C-7), 126.0 (C-5), 124.2 (C-6), 122.1 (C-5'), 120.3 (C-4a), 117.5 (C-8), 113.4 (C-3'), 99.7 (C-3). Minor isomer: 178.8 (C-4), 165.3 (C-2), 154.7 (C-9), 154.5 (C-8a), 149.3 (C-6'), 149.25 (C-2'), 139.0 (C-4'), 134.9 (C-7), 126.7 (C-5), 124.5 (C-6), 122.0 (C-5'), 120.7 (C-4a), 117.4 (C-8), 113.2 (C-3'), 100.0 (C-3). IR $\nu_{\max }\left(\mathrm{cm}^{-1}\right) 3218,1685,1640,1459$, 760. APCI-HRMS $m / z$ calcd. for $\mathrm{C}_{15} \mathrm{H}_{11} \mathrm{~N}_{2} \mathrm{O}_{3}, 267.0764$, $[\mathrm{M}+\mathrm{H}]^{+}$found 267.0748. Purity (HPLC): $99 \%$.

(3E/Z)-3(\{[2-(Pyridin-2-yl)ethyl]amino\}methylidene)-3,4-dihydro-2H-1-benzopyran-2,4-dione (14j) The title compound was prepared from chromone-3-carboxylic acid and 2-(2-pyridyl)ethylamine in a yield of 53\%: $\mathrm{mp}$. 144.7$145.8^{\circ} \mathrm{C}$ (methanol), colourless crystals. Ratio of major isomer: minor isomer 1:0.4. ${ }^{1} \mathrm{H}$ NMR $\left(600 \mathrm{MHz}\right.$, DMSO- $\left.d_{6}\right) \delta$ Major isomer: 11.81 (s, 1H, NH), 8.56-8.49 (m, 1H, H-6'), 8.40 (br s, 1H, H-9), 7.93-7.86 (m, 1H, H-5), 7.76-7.69 (m, 1H, H-4'), 7.66-7.58 (m, 1H, H-7), 7.33-7.21 (m, 4H, H-3', H-5', H-6, H-8), 4.01 (t, $J=6.7$ Hz, 2H, H-10), 3.16 (t, $J=6.6 \mathrm{~Hz}, 2 \mathrm{H}, \mathrm{H}-11)$. Minor isomer: $10.61(\mathrm{~s}, 1 \mathrm{H}, \mathrm{NH})$, 8.56-8.49 (m, 2H, H-9, H-6'), 7.93-7.86 (m, 1H, H-5), 7.767.69 (m, 1H, H-4'), 7.66-7.58 (m, 1H, H-7), 7.33-7.21 (m, 4H, H-3', H-5', H-6, H-8), 4.01 (t, $J=6.7 \mathrm{~Hz}, 2 \mathrm{H}, \mathrm{H}-10$ ), $3.16(\mathrm{t}, J=6.6 \mathrm{~Hz}, 2 \mathrm{H}, \mathrm{H}-11) .{ }^{13} \mathrm{C}$ NMR $(151 \mathrm{MHz}$, DMSO$\left.d_{6}\right) \delta$ Major isomer: 179.2 (C-4), 162.7 (C-2), 162.2 (C-9), 157.8 (C-2'), 154.1 (C-8a), 149.1 (C-6'), 136.7 (C-4'), 134.2 (C-7), 125.3 (C-5), 123.9 (C-6), 123.6, 121.9 (C-3', C-5')*, 120.3 (C-4a), 116.9 (C-8), 95.6 (C-3), 49.3 (C-10), 36.97 (C-11). Minor isomer: 176.9 (C-4), 163.2 (C-2), 160.6 (C-9), 157.9 (C-2'), 154.2 (C-8a), 149.0 (C-6'), 136.7 (C-4'), 134.3 (C-7), 125.7 (C-5), 124.0 (C-6), 123.6, 121.9, (C-3', C-5')*, 120.4 (C-4a), 117.0 (C-8), 95.4 (C-3), 49.5 (C-10), 37.1 $(\mathrm{C}-11)$. IR $\nu_{\max }\left(\mathrm{cm}^{-1}\right): 3197,1708,1605,1463,762$. APCIHRMS $m / z$ calcd. for $\mathrm{C}_{17} \mathrm{H}_{15} \mathrm{~N}_{2} \mathrm{O}_{3}, 295.1077,[M+H]^{+}$ found 295.1071. Purity (HPLC): $100 \%$. *In no particular order.

\section{Measurement of $I C_{50}$ values for the inhibition of MAO}

Recombinant human MAO-A and MAO-B enzymes served as enzyme sources [49]. The enzyme reactions were carried out in white 96-well microtiter plates (Eppendorf) in potassium phosphate buffer ( $\mathrm{pH} 7.4,100 \mathrm{mM}$, made isotonic with $\mathrm{KCl}$ ). The final volume of the reactions was $200 \mu \mathrm{L}$ and contained kynuramine $(50 \mu \mathrm{M})$, the test inhibitors $(0.003-100 \mu \mathrm{M})$ and MAO-A $(0.0075 \mathrm{mg}$ protein/ $\mathrm{mL})$ or MAO-B $(0.015 \mathrm{mg}$ protein $/ \mathrm{mL})$. Stock solutions of the test inhibitors were prepared in DMSO and added to the reactions to yield a final concentration of $4 \%$. Reactions serving as negative controls were carried out in the absence of inhibitor. The enzyme reactions were initiated with the addition of the MAO enzymes and were subsequently incubated for $20 \mathrm{~min}$ at $37^{\circ} \mathrm{C}$ in a convection oven. At endpoint, the reactions were terminated with the addition of $80 \mu \mathrm{L}$ sodium hydroxide $(2 \mathrm{~N})$ and the concentration of 4-hydroxyquinoline, the product of kynuramine oxidation by MAO, was measured by fluorescence spectrophotometry $\left(\lambda_{\mathrm{ex}}=310 \mathrm{~nm} ; \lambda_{\mathrm{em}}=400 \mathrm{~nm}\right)$. For this purpose, a linear calibration curve was constructed with authentic 4-hydroxyquinoline $(0.047-1.56 \mu \mathrm{M})$. The rates of MAO-catalysed 4-hydroxyquinoline formation thus measured were fitted to the one-site competition model of the Prism 5 software package (GraphPad). This gave sigmoidal plots of rate versus logarithm of inhibitor concentration from which the $\mathrm{IC}_{50}$ values were estimated. $\mathrm{IC}_{50}$ values were measured in triplicate and are reported as the mean \pm standard deviation (SD).

\section{Dialysis studies}

Dialysis was carried out with Slide-A-Lyzer dialysis cassettes (Thermo Scientific) with a molecular weight cut-off of 10000 and a sample volume capacity of $0.5-3 \mathrm{~mL}$ [49]. The test inhibitor (at a concentration equal to $4 \times \mathrm{IC}_{50}$ ) and MAO-B $(0.03 \mathrm{mg}$ protein $/ \mathrm{mL})$ were prepared to a final volume of $0.8 \mathrm{~mL}$ in the dialysis buffer (potassium phosphate buffer, $100 \mathrm{mM}, \mathrm{pH} 7.4,5 \%$ sucrose). Stock solutions of the inhibitor were prepared in DMSO and added to the buffer to yield $4 \%$ DMSO. These samples were preincubated for $15 \mathrm{~min}$ at $37{ }^{\circ} \mathrm{C}$ and were subsequently dialysed at $4{ }^{\circ} \mathrm{C}$ in $80 \mathrm{~mL}$ of dialysis buffer. The dialysis buffer was replaced with fresh buffer at $3 \mathrm{~h}$ and $7 \mathrm{~h}$ after the start of dialysis. As positive control, MAO-B was similarly preincubated and dialysed in the presence of the irreversible inhibitor, (R)-deprenyl $\left(\mathrm{IC}_{50}=0.079 \mu \mathrm{M}\right)$ [57]. As negative control dialysis of the enzyme was carried out in the absence of the inhibitor. After $24 \mathrm{~h}$ of dialysis, $250 \mu \mathrm{L}$ of the dialysed samples was diluted twofold with the addition of $250 \mu \mathrm{L}$ kynuramine (dissolved in potassium phosphate buffer, $100 \mathrm{mM}, \mathrm{pH} 7.4$, made isotonic with $\mathrm{KCl}$ ) to yield reactions with a final volume of $500 \mu \mathrm{L}$ and containing kynuramine $(50 \mu \mathrm{M})$, MAO-B $(0.015 \mathrm{mg}$ protein $/ \mathrm{mL})$ and test inhibitor $\left(2 \times \mathrm{IC}_{50}\right)$. The reactions (contained in $1.5 \mathrm{~mL}$ microcentrifuge tubes) were incubated at $37^{\circ} \mathrm{C}$ in a waterbath and after 20 min were terminated with the addition of $400 \mu \mathrm{L}$ sodium hydroxide $(2 \mathrm{~N})$. After addition of $1000 \mu \mathrm{L}$ water, the concentrations of 4-hydroxyquinoline were measured by fluorescence spectrophotometry $\left(\lambda_{\mathrm{ex}}=310 \mathrm{~nm} ; \lambda_{\mathrm{em}}=400 \mathrm{~nm}\right)$ employing a $3.5-\mathrm{mL}$ quartz cuvette (pathlength $10 \times 10 \mathrm{~mm}$ ). To quantify 4-hydroxyquinoline, a linear calibration curve was constructed with authentic 4-hydroxyquinoline 
$(0.047-1.56 \mu \mathrm{M})$. For comparison, undialysed mixtures of MAO-B and the test inhibitor were maintained at $4{ }^{\circ} \mathrm{C}$ for $24 \mathrm{~h}$ and subsequently diluted twofold and assayed as above. All reactions were carried out in triplicate, and the residual enzyme catalytic rates were expressed as mean $\pm \mathrm{SD}$.

\section{Lineweaver-Burk plots and $K_{i}$ value calculations}

A set consisting of four Lineweaver-Burk plots were constructed. The first plot was constructed in the absence of inhibitor, while the remaining three plots were constructed in the presence of the test inhibitor at concentrations of $1 / 2 \times \mathrm{IC}_{50}, 1 \times \mathrm{IC}_{50}$ and $1 \frac{1 / 4}{4} \times \mathrm{IC}_{50}$. The enzyme-substrate, kynuramine, was used at concentrations ranging from 15 to $250 \mu \mathrm{M}$, while the final enzyme concentration was $0.015 \mathrm{mg}$ protein $/ \mathrm{mL}$. All incubations were carried out in $1.5 \mathrm{~mL}$ microcentrifuge tubes to a volume of $500 \mu \mathrm{L}$. The MAO-B catalytic activity was measured by fluorescence spectrophotometry as described for the dialysis study. $K_{i}$ values were estimated from plots of the slopes of the Lineweaver-Burk plots versus inhibitor concentration, where the $\mathrm{x}$-axis intercept equals $-K_{i}$.

Acknowledgements The NMR and MS spectra were recorded by André Joubert and Johan Jordaan of the Laboratory for Analytical Services (LAS) in the focus area Chemical Resource Beneficiation, while HPLC analysis was carried out by Jan du Preez of the Analytical Technology Laboratory (ATL) at the North-West University (NWU). X-ray crystallography was carried out by Johan Jordaan.

Funding The financial assistance of the National Research Foundation (NRF) of South Africa [Grant specific unique reference numbers (UID) $85642,96180,76308]$ towards this research is hereby acknowledged. The Grantholders acknowledge that opinions, findings and conclusions or recommendations expressed in any publication generated by the NRF supported research are that of the authors, and that the NRF accepts no liability whatsoever in this regard.

\section{Compliance with ethical standards}

Conflict of interest The authors declare that they have no conflict of interest.

\section{References}

1. Brichta L, Greengard P, Flajolet M (2013) Advances in the pharmacological treatment of Parkinson's disease: targeting neurotransmitter systems. Trends Neurosci 36:543-554. https://doi. org/10.1016/j.tins.2013.06.003

2. Wood-Kaczmar A, Gandhi S, Wood NW (2006) Understanding the molecular causes of Parkinson's disease. Trends Mol Med 12:521-528. https://doi.org/10.1016/j.molmed.2006.09.007

3. Poewe W, Seppi K, Tanner CM, Halliday GM, Brundin P, Volkmann J, Schrag AE, Lang AE (2017) Parkinson disease. Nat Rev Dis Primers 3:17013. https://doi.org/10.1038/nrdp.2017.13

4. Dauer W, Przedborski S (2003) Parkinson's disease: mechanisms and models. Neuron 39:889-909
5. Schwarzschild MA, Agnati L, Fuxe K, Chen JF, Morelli M (2006) Targeting adenosine A2A receptors in Parkinson's disease. Trends Neurosci 29:647-654. https://doi.org/10.1016/j.tins.2006.09.004

6. Lees AJ, Hardy J, Revesz T (2009) Parkinson's disease. Lancet 373:2055-2066. https://doi.org/10.1016/S0140-6736(09)60492-X

7. Stocchi F (2014) Therapy for Parkinson's disease: what is in the pipeline? Neurotherapeutics 11:24-33. https://doi.org/10.1007/ s13311-013-0242-1

8. LeWitt PA, Taylor DC (2008) Protection against Parkinson's disease progression: clinical experience. Neurotherapeutics 5:210 225. https://doi.org/10.1016/j.nurt.2008.01.007

9. Youdim MB, Edmondson D, Tipton KF (2006) The therapeutic potential of monoamine oxidase inhibitors. Nat Rev Neurosci 7:295-309. https://doi.org/10.1038/nrn1883

10. Shih JC, Chen K, Ridd MJ (1999) Monoamine oxidase: from genes to behavior. Annu Rev Neurosci 22:197-217. https://doi. org/10.1146/annurev.neuro.22.1.197

11. Binda C, Newton-Vinson P, Hubalek F, Edmondson DE, Mattevi A (2002) Structure of human monoamine oxidase B, a drug target for the treatment of neurological disorders. Nat Struct Biol 9:22-26. https://doi.org/10.1038/nsb732

12. Son SY, Ma J, Kondou Y, Yoshimura M, Yamashita E, Tsukihara $\mathrm{T}$ (2008) Structure of human monoamine oxidase A at 2.2-A resolution: the control of opening the entry for substrates/inhibitors. Proc Natl Acad Sci USA 105:5739-5744. https://doi.org/10.1073/ pnas.0710626105

13. Henchcliffe C, Schumacher HC, Burgut FT (2005) Recent advances in Parkinson's disease therapy: use of monoamine oxidase inhibitors. Expert Rev Neurother 5:811-821. https://doi. org/10.1586/14737175.5.6.811

14. Youdim MB, Bakhle YS (2006) Monoamine oxidase: isoforms and inhibitors in Parkinson's disease and depressive illness. Br J Pharmacol 147(Suppl 1):S287-S296. https://doi.org/10.1038/ sj.bjp.0706464

15. Carradori S, Silvestri R (2015) New frontiers in selective human MAO-B inhibitors. J Med Chem 58:6717-6732. https://doi. org/10.1021/jm501690r

16. Carradori S, Petzer JP (2015) Novel monoamine oxidase inhibitors: a patent review (2012-2014). Expert Opin Ther Pat 25:91110. https://doi.org/10.1517/13543776.2014.982535

17. Zecca L, Youdim MB, Riederer P, Connor JR, Crichton RR (2004) Iron, brain ageing and neurodegenerative disorders. Nat Rev Neurosci 5:863-873. https://doi.org/10.1038/nrn1537

18. Fowler JS, Volkow ND, Wang GJ, Logan J, Pappas N, Shea C, MacGregor R (1997) Age-related increases in brain monoamine oxidase $\mathrm{B}$ in living healthy human subjects. Neurobiol Aging 18:431-435

19. deSouza RM, Schapira A (2017) Safinamide for the treatment of Parkinson's disease. Expert Opin Pharmacother 18:937-943. https ://doi.org/10.1080/14656566.2017.1329819

20. Da Prada M, Zurcher G, Wuthrich I, Haefely WE (1988) On tyramine, food, beverages and the reversible MAO inhibitor moclobemide. J Neural Transm Suppl 26:31-56

21. Flockhart DA (2012) Dietary restrictions and drug interactions with monoamine oxidase inhibitors: an update. J Clin Psychiatry 73(Suppl 1):17-24. https://doi.org/10.4088/JCP.11096su1c.03

22. Gnerre C, Catto M, Leonetti F, Weber P, Carrupt PA, Altomare C, Carotti A, Testa B (2000) Inhibition of monoamine oxidases by functionalized coumarin derivatives: biological activities, QSARs, and 3D-QSARs. J Med Chem 43:4747-4758

23. Chimenti F, Fioravanti R, Bolasco A, Chimenti P, Secci D, Rossi F, Yanez M, Orallo F, Ortuso F, Alcaro S (2009) Chalcones: a valid scaffold for monoamine oxidases inhibitors. J Med Chem 52:2818-2824. https://doi.org/10.1021/jm801590u

24. Gamal-Eldeen AM, Djemgou PC, Tchuendem M, Ngadjui BT, Tane P, Toshifumi H (2007) Anti-cancer and immunostimulatory 
activity of chromones and other constituents from Cassia petersiana. Z Naturforsch C 62:331-338

25. Djemgou PC, Gatsing D, Tchuendem M, Ngadjui BT, Tane P, Ahmed AA, Gamal-Eldeen AM, Adoga GI, Hirata T, Mabry TJ (2006) Antitumor and immunostimulatory activity of two Chromones and other constituents from Cassia petersiana. Nat Prod Commun 1:961-968

26. Kuroda M, Uchida S, Watanabe K, Mimaki Y (2009) Chromones from the tubers of Eranthis cilicica and their antioxidant activity. Phytochemistry 70:288-293. https://doi.org/10.1016/j.phyto chem.2008.12.002

27. Zhou T, Shi Q, Lee KH (2010) Efficient microwave-assisted one-pot preparation of angular 2,2-dimethyl-2H-chromone containing compounds. Tetrahedron Lett 51:4382-4386. https://doi.org/10.1016/j. tetlet.2010.06.058

28. Martens S, Mithofer A (2005) Flavones and flavone synthases. Phytochemistry 66:2399-2407. https://doi.org/10.1016/j.phyto chem.2005.07.013

29. Binbuga N, Ruhs C, Hasty JK, Henry WP, Schultz TP (2008) Developing environmentally benign and effective organic wood preservatives by understanding the biocidal and non-biocidal properties of extractives in naturally durable heartwood. Holzforschung 62:264269. https://doi.org/10.1515/Hf.2008.038

30. Sumiyoshi M, Kimura Y (2010) Enhancing effects of a chromone glycoside, eucryphin, isolated from Astilbe rhizomes on burn wound repair and its mechanism. Phytomedicine 17:820-829. https://doi. org/10.1016/j.phymed.2010.01.010

31. Jovanovic SV, Steenken S, Tosic M, Marjanovic B, Simic MG (1994) Flavonoids as antioxidants. J Am Chem Soc 116:4846-4851. https://doi.org/10.1021/ja00090a032

32. Machado NFL, Marques MPM (2010) Bioactive chromone derivatives-structural diversity. Curr Bioact Compd 6:76-89

33. Legoabe LJ, Petzer A, Petzer JP (2012) Inhibition of monoamine oxidase by selected C6-substituted chromone derivatives. Eur J Med Chem 49:343-353. https://doi.org/10.1016/j.ejmech.2012.01.037

34. Legoabe LJ, Petzer A, Petzer JP (2012) Selected C7-substituted chromone derivatives as monoamine oxidase inhibitors. Bioorg Chem 45:1-11. https://doi.org/10.1016/j.bioorg.2012.08.003

35. Legoabe LJ, Petzer A, Petzer JP (2012) Selected chromone derivatives as inhibitors of monoamine oxidase. Bioorg Med Chem Lett 22:5480-5484. https://doi.org/10.1016/j.bmcl.2012.07.025

36. Alcaro S, Gaspar A, Ortuso F, Milhazes N, Orallo F, Uriarte E, Yanez M, Borges F (2010) Chromone-2- and -3-carboxylic acids inhibit differently monoamine oxidases A and B. Bioorg Med Chem Lett 20:2709-2712. https://doi.org/10.1016/j.bmcl.2010.03.081

37. Gaspar A, Silva T, Yanez M, Vina D, Orallo F, Ortuso F, Uriarte E, Alcaro S, Borges F (2011) Chromone, a privileged scaffold for the development of monoamine oxidase inhibitors. J Med Chem 54:5165-5173. https://doi.org/10.1021/jm2004267

38. Gaspar A, Reis J, Fonseca A, Milhazes N, Vina D, Uriarte E, Borges F (2011) Chromone 3-phenylcarboxamides as potent and selective MAO-B inhibitors. Bioorg Med Chem Lett 21:707-709. https://doi. org/10.1016/j.bmcl.2010.11.128

39. Cagide F, Silva T, Reis J, Gaspar A, Borges F, Gomes LR, Low JN (2015) Discovery of two new classes of potent monoamine oxidaseB inhibitors by tricky chemistry. Chem Commun 51:2832-2835. https://doi.org/10.1039/c4cc08798d

40. Staab HA (1962) New methods of preparative organic chemistry IV. Synthesis using heterocyclic amides (azolides). Angew Chem Int Edit 1:351-367

41. Traven VF, Ivanov IV, Lebedev VS, Chibisova TA, Milevskii BG, Solov'eva NP, Polshakov VI, Alexandrov GG, Kazheva ON, Dyachenko OA (2010) E/Z(C=C)-Isomerization of enamines of 3-formyl-4-hydroxycoumarin induced by organic solvents. Russ Chem B 59:1605-1611. https://doi.org/10.1007/s11172-010-0284-Z

42. Okumura K, Kondo K, Oine T, Inoue I (1974) The synthesis of chromone-3-carboxanilides. Chem Pharm Bull 22:331-336
43. Ibrahim MA (2009) Ring transformation of chromone-3-carboxamide. Tetrahedron 65:7687-7690. https://doi.org/10.1016/j. tet.2009.06.107

44. Milevskii BG, Chibisova TA, Solov'eva NP, Anisimova OS, Lebedev VS, Ivanov IV, Traven VF (2013) Synthesis and structure of Schiff bases derived from 3-formyl-4-hydroxycoumarin and diamines. Chem Heterocycl Compd 48:1781-1792. https://doi. org/10.1007/s10593-013-1209-1

45. Ishar MPS, Kumar K, Singh R (1998) Thermal rearrangements of C-(4-oxo-4H[1]benzopyran-3-yl)-N-phenylnitrone-a route to novel quinolino[2,3-b]chroman-12-ones. Tetrahedron Lett 39:6547-6550. https://doi.org/10.1016/S0040-4039(98)01362-8

46. Alberola A, Calvo L, Gonzalez-Ortega A, Encabo AP, Sanudo MC (2001) Synthesis of [1]benzopyrano [4,3-b] pyrrol-4(1H)-ones from 4-chloro-3-formylcoumarin. Synthesis-Stuttgart 2001:1941-1948

47. Strakova I, Petrova M, Belyakov S, Strakovs A (2006) Reactions of 4-chloro-3-formylcoumarine with primary amines. Khim Geterotsikl 5:660-668

48. Novaroli L, Reist M, Favre E, Carotti A, Catto M, Carrupt PA (2005) Human recombinant monoamine oxidase $\mathrm{B}$ as reliable and efficient enzyme source for inhibitor screening. Bioorg Med Chem 13:62126217. https://doi.org/10.1016/j.bmc.2005.06.043

49. Mostert S, Petzer A, Petzer JP (2015) Indanones as high-potency reversible inhibitors of monoamine oxidase. ChemMedChem 10:862-873. https://doi.org/10.1002/cmdc.201500059

50. Petzer A, Pienaar A, Petzer JP (2013) The inhibition of monoamine oxidase by esomeprazole. Drug Res (Stuttg) 63:462-467. https:// doi.org/10.1055/s-0033-1345163

51. Costas-Lago MC, Besada P, Rodriguez-Enriquez F, Vina D, Vilar S, Uriarte E, Borges F, Teran C (2017) Synthesis and structureactivity relationship study of novel 3-heteroarylcoumarins based on pyridazine scaffold as selective MAO-B inhibitors. Eur J Med Chem 139:1-11. https://doi.org/10.1016/j.ejmech.2017.07.045

52. Ahmad S, Zaib S, Jalil S, Shafiq M, Ahmad M, Sultan S, Iqbal M, Aslam S, Iqbal J (2018) Synthesis, characterization, monoamine oxidase inhibition, molecular docking and dynamic simulations of novel 2,1-benzothiazine-2,2-dioxide derivatives. Bioorg Chem 80:498-510. https://doi.org/10.1016/j.bioorg.2018.04.012

53. Is YS, Durdagi S, Aksoydan B, Yurtsever M (2018) Proposing novel MAO-B hit inhibitors using multidimensional molecular modeling approaches and application of binary QSAR models for prediction of their therapeutic activity, pharmacokinetic and toxicity properties. ACS Chem Neurosci 9:1768-1782. https://doi.org/10.1021/acsch emneuro.8b00095

54. Binda C, Wang J, Pisani L, Caccia C, Carotti A, Salvati P, Edmondson DE, Mattevi A (2007) Structures of human monoamine oxidase B complexes with selective noncovalent inhibitors: safinamide and coumarin analogs. J Med Chem 50:5848-5852. https://doi. org/10.1021/jm070677y

55. Bandyopadhyay C, Sur KR, Patra R, Sen A (2000) Synthesis of coumarin derivatives from 4-oxo-4H-1-benzopyran-3-carboxaldehyde via 3-(arylaminomethylene)chroman-2,4-dione. Tetrahedron 56:3583-3587. https://doi.org/10.1016/S0040-4020(00)00269-6

56. Fitton AO, Frost JR, Houghton PG, Suschitzky H (1997) Reactions of formylchromone derivatives. Part 2. Addition reactions of 3-(aryliminomethyl)chromones. J Chem Soc Perkin Trans 10:1691-1694

57. Petzer A, Harvey BH, Wegener G, Petzer JP (2012) Azure B, a metabolite of methylene blue, is a high-potency, reversible inhibitor of monoamine oxidase. Toxicol Appl Pharmacol 258:403-409. https ://doi.org/10.1016/j.taap.2011.12.005

Publisher's Note Springer Nature remains neutral with regard to jurisdictional claims in published maps and institutional affiliations. 


\section{Affiliations}

\section{Annah N. Mpitimpiti ${ }^{1}$. Jacobus P. Petzer ${ }^{1,2}$ - Anél Petzer ${ }^{1,2}$ • Johannes H. L. Jordaan ${ }^{3} \cdot$ Anna C. U. Lourens ${ }^{1,2}$}

1 Centre of Excellence for Pharmaceutical Sciences, NorthWest University, Private Bag X6001, Potchefstroom 2520, South Africa

2 Pharmaceutical Chemistry, School of Pharmacy, North-West University, Private Bag X6001, Potchefstroom 2520,

South Africa
3 Research Focus Area for Chemical Resource

Beneficiation, North-West University, Private Bag X6001, Potchefstroom 2520, South Africa 